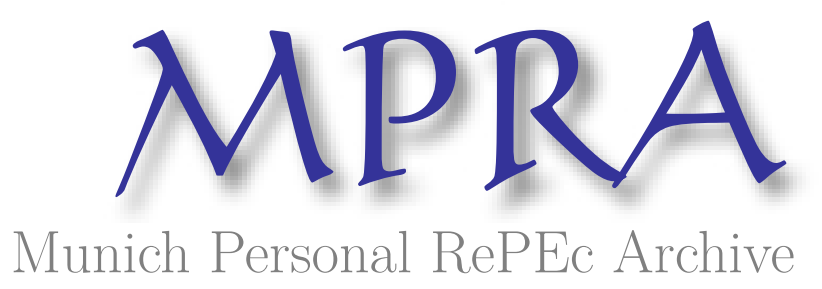

Cash, Funeral Benefits or Nothing at All: How to Incentivize Family Consent for Organ Donation

Pham, Vinh

Waseda University

19 July 2021

Online at https://mpra.ub.uni-muenchen.de/110471/

MPRA Paper No. 110471, posted 05 Nov 2021 14:38 UTC 


\title{
Cash, Funeral Benefits or Nothing at All: How to Incentivize Family Consent for Organ Donation
}

\author{
Vinh Pham \\ Graduate School of Economics, Waseda University, 1-6-1 Nishiwaseda, Shinjuku-ku, Tokyo 169-8050, Japan \\ vpham@conncoll.edu
}

\begin{abstract}
Incentives, such as funeral expense reimbursements and direct payments for surviving families, have been suggested to increase organ supply from post-mortem donors. Following Heyman and Ariely's 2004 findings on the impact of gift labeling and reward magnitude on behaviors in altruistic environments, this study utilizes a full factorial survey design to examine subjects' moral assessment of funeral benefits and cash prizes, and the effects these incentives had on the willingness to provide family consent (WTC). Regression analysis showed that funeral aids, when presented as gifts, outperformed direct payments in all ethical principles. Furthermore, a full funeral service without a revealed value was found to increase WTC by 8.5 percent from the current system.
\end{abstract}

Keywords: organ donation, incentives, prosocial behavior, factorial survey

JEL classification: D12, D64, I18

\footnotetext{
I based this article on my unpublished master's thesis at the University of Cologne (Pham, 2019). I'm sincerely thankful for the support given by Prof. Masao Ogaki, Prof. Kiryl Khalmetski, Prof. Mónika López-Anuarbe, Prof. David Chavanne, Prof. Donald Peppard, Tina \& Marc Forster, and my friends who participated in the pilot survey. I would also like to thank two anonymous reviewers, who offered very valuable feedback to improve the article.
} 


\section{Introduction}

A major achievement of modern medical science, organ transplantation has been obstructed from its larger contribution to saving and improving lives by the substantial shortage of organ supply. More seriously, the gap between demand and supply in organ transplantation has widened every year, because supply has stayed flat, while technology advancements and aging populations have rapidly expanded the demand for transplantation (Caplan 2016, 1; Levy 2018, 402-403). To battle this challenge, policymakers have focused on tackling causes of organ shortage, most notably in surviving families' overruling of the presumed consent and deceased patients' wishes to donate after death - a practice allowed formally or informally in various jurisdictions (Shaw et al. 2017, 482-484; National Academies of Sciences, Engineering, and Medicine 2018). Among different solutions for the issue, financial incentives, such as direct payments and funeral expense reimbursements, have been suggested in organ transplant literature to help increase the supply (Blair \& Kaserman 1991; Becker \& Elías 2007; Arnold et al 2002, Bryce et al. 2005; Coppen et al. 2010, 167-168).

Following Auspurg and Hinz's 2014 guidance for factorial survey designs and Heyman and Ariely's 2004 findings about financial rewards in prosocial acts, this study examines the effects of different incentivizing methods, namely funeral benefits and cash payments, on subjects' ethical assessment and willingness to provide family consent. The analysis on moral judgments found that funeral aids, when presented as gifts to respondents, were perceived to be more ethically acceptable than direct payments in all criteria, such as honoring the deceased donor or keeping away the commercialization of human organs. Most notably, regression analysis found that a full funeral service without a revealed value would improve family consent by $8.5 \%$ from the current incentive-free system ( $\mathrm{P}$-value $<0.05$ ). 
The following section provides a review of family refusal in cadaveric organ donation and financial incentives to encourage consent that have been proposed and implemented. Sections 3 and 4 analyze the theoretical framework of incentivizing in altruistic environments and describe the factorial survey setups of the experiments. Section 5 presents the regression results, followed by discussions on notable findings and applicable extensions.

\section{Review of The Issue}

\subsection{Family refusal and overrule in post-mortem organ donation}

Many families refuse to allow organ donation after death, which has created a major obstacle for cadaveric transplantation (Girlanda 2016, Shaw et al. 2017). Moreover, family overrule against the patient's wish to donate after death is permitted, formally or informally, in both systems with presumed consent (also known as "opt-out") and those with informed consent (“opt-in”) (Shaw et al. 2017, 483). To mitigate this challenge, some countries, such as Austria, Singapore and France, adopted "hard opt-out" policies, which legally disallowed family overrule in all cases (BBC Reality Check Team 2017; Willsher 2017). However, in practice, hospitals in Austria were still documented to allow informal family overrule, while Belgium granted family overturning presumed consent when the deceased did not have an officially recorded wish to become a donor (Shaw et al. 2017, 483-484).

Several sociodemographic factors have been shown to have strong associations with surviving families' willingness to permit transplantation. Siminoff et al. (2001) highlighted the links between family consent for post-mortem organ donation and the patient's ethnicity, age and gender. In particular, families of white patients, younger patients, and male patients were found to be significantly more likely to allow cadaveric organ donation. Age and ethnicity 
were also confirmed to be impactful factors in the level of family consent by Rodrigue, Cornell, and Howard (2006). In comparison, Barber et al. (2006) found that nonwhite families refused organ donation twice as much as white families in the United Kingdom, but did not identify any significant roles of age and gender of potential donors in the surviving families' decision. Furthermore, Ghorbani et al. (2011) and Mojtabaee et al. (2018) found that religious beliefs were among the leading causes for refusal to donate in Iran: $43.6 \%$ of Sunni Muslim families rejected donation compared to $8.6 \%$ of families from other religious backgrounds. These findings were in line with those of Mithra et al. (2013) on donor registration in India: Christians and Hindus were significantly more willing to donate their organs after death than Muslims.

The type of death also played an important role in surviving families' decisions. The majority of donated organs come from brain dead donors, while donation after circulatory death, defined as the irreversible loss of all heart and lung functions, is practiced in only a handful of countries (Human Tissue Authority 2017; Smith et al. 2019). Consequently, denial and rejection of brain death criteria are among the most prevalent reasons for surviving families' refusal to donate (Anker \& Feely 2010; Brown et al. 2010; Ghorbani et al. 2011; Mojtabaee et al. 2018). Indeed, several studies on solutions to increase organ donation underlined the role of education to widen public understanding and acceptance of brain death as actual death (Wig, Gupta \& Kailash 2003; Yilmatz 2011; Ralph et al. 2014).

In addition, the role of sentimental and psychological environments, in which families were inquired to make the decision to donate, cannot be ignored. Because transplants must take place almost immediately after death, surviving families have to make the urgent decision under a high level of grief and stress. Behavioral literature has recorded the significant role 
negative emotion could play in decision making: upset individuals could reject tangible monetary gains (Pillutla \& Murnighan 1996; Harlé \& Sanfey 2007), experience a "reverse endowment effect" by offering higher buying prices than selling prices of the same object (Lerner, Small \& Loewenstein 2004), or exhibit less altruistic behaviors than those in a good mood (Capra 2004). The findings in behavioral economics could have implications in the organ donation settings, as negative feelings might affect family consent and reaction to donation incentives. Indeed, literature in organ transplantation recorded that family consent was influenced by several sentimental factors that were unique to the situation, such as unstable family mood, disagreement between family members, expectation of a miracle that could revive the deceased, and shifting moods caused by timing and sensitivity of the hospital staff who inquired about organ donation (Ghorbani et al. 2011; Mojtabaee et al. 2018; Rodrigue et al 2006; Sque, Long \& Payne 2005).

Furthermore, Siminoff et al. $(2001,74)$ underlined the strong connections between families' consent giving and their prior knowledge of the deceased's wish to donate: $66 \%$ of families that had communicated with the patients about post-mortem donation gave their consent, while $86 \%$ of those who believed the patients would have wanted to donate, even without an explicit discussion, gave donation permission. These significant links between consenting and preceding knowledge of the donor's wishes were also confirmed by other studies documenting cadaveric transplantation (Rodrigue et al. 2006; Ghorbani et al. 2011; Mojtabaee et al. 2018). Furthermore, Kessler and Roth's 2014 experiment found that subjects supported next-of-kin consent of unregistered donors in an opt-in system, where the deceased had not actively registered to donate, by $43 \%$ more than the same type of consent in an optout system, where the deceased had explicitly refused to donate. 
In short, the literature documenting surviving families' decision on post-mortem organ transplantation has found the following factors to strongly affect the consent to donate:

- Ethnicity and religious beliefs of the family

- Age and gender of the patient

- Type of death (rejection of brain death criteria)

- Prior knowledge and beliefs about the patient's wish to donate

- The family's feelings and mood when the donation question was asked

In Section 4, the study will incorporate these factors in the experimental design.

\subsection{International cases of financial inducements in organ donation}

a. Iran's market system for kidney trading

As of 2019, Iran seems to be the only country where an official market structure for organ sale exists (Bengali \& Mostaghim 2017). The Iranian central government operates a kidney trading system, through which anonymous buyers and sellers are matched; the government pays for the cost of the operation and sets an amount equal to U.S. $\$ 4,600$ as the compensation the kidney recipient must send to the donor (Bengali \& Mostaghim 2017). Eleven years after the trading system went into effect in 1988, both the shortage of available kidneys and the transplant waitlist were eliminated in Iran (Ghods \& Savaj 2006, 1136). The trading system, however, has also contributed to worsening social equity: $84 \%$ of the kidney supply came from poor donors, while only $50 \%$ of recipients were poor (Hippen 2008, 5; Ghods \& Savaj 2006, 1141). Kidney sellers also reported dissatisfaction with the healthcare 
services after transplants and frequent shaming from their own communities (Zargooshi 2001).

\section{b. South Korea's financial incentives for surviving families}

South Korea is a rare example of a system that allows financial incentives for organ donation. The 2006 provision of the Organ Transplant Act introduced financial inducements in order to battle organ shortage: in the case of a brain-death donation, an amount equivalent to U.S. $\$ 4,500$ could be given to the surviving family (Lee \& Kim 2009, 3554). Remarkably, the policy specified that the cash was intended as compensation for funeral expenses and hospital fees, as well as consolatory money for the family's loss. The implementation of this policy sets South Korea apart from other nations in its regulatory framework in several aspects:

- The government's approval of this law showed a legal acceptance of a monetary compensation for donation consent. Furthermore, the considerable payment of U.S. $\$ 4,500$ would enter the debatable zone of an excessive inducement that could interfere with the voluntariness of organ donation, as argued by Arnold et al. $(2002,1366)$.

- Coverage for funeral and hospital expenses is regarded as an acceptable purpose of compensation by the South Korean government. As discussed in the next section, introducing a financial incentive to reimburse the funeral cost of a deceased donor has also been suggested by researchers (Arnold et al 2002, Bryce et al. 2005; Coppen et al. 2010; 167-168; Levy 2018, 414-417).

- Consolation for the loss of the family is also accepted as an appropriate intention of the incentive. This purpose of the compensation would come very close to a direct payment 
for the consent, which has been deemed low in moral appropriateness but high in inducing donation (Arnold et al. 2002, 1365).

It should be noted that the reward implemented in South Korea was only part of a series of reforms to increase organ donation, which included the 2000 introduction of the National Transplant Act and the 2009 establishment of the Korea Organ Donor Agency (Soyama \& Eguchi 2016, 389). South Korea succeeded in expanding its donation rate from $1.3 \mathrm{pmp}$ in 2000 to 9.95 pmp in 2017, ranking far ahead of its neighbors (Min et al. 2010; IRODaT 2018, 3). In exploring the role of singular factors affecting donation consent, Soyama and Eguchi $(2016,389)$ highlighted that the wide media coverage of boxer Yo-Sam Choi's donation case contributed to a $73 \%$ increase in donation after brain death between 2007 and 2008, the largest annual increase. On the other hand, it was unclear whether the 2006 financial incentive for surviving families played a significant role in the overall growth of donation in South Korea, as there was only a 0.2 pmp increase in the donation rate between 2006 and 2007 - an insignificant change compared to far larger growths in other years (Min et al. 2010).

Besides South Korea and Iran, there are only a few other countries that have employed certain forms of financial compensation in organ donation. In Spain, where the donation rate is the world's highest, although federal laws mandate that organ donation must be voluntary, altruistic, and free of financial inducements, regional agencies still contribute to funeral expenses of post-mortem donors, in cases of lack of insurance coverage (IRODaT 2018, 3; Rodríguez-Arias, Wright and Paredes 2010, 1110). In the 1980s, the Kuwaiti government offered reimbursements for travel and funeral expenses for families of deceased donors from abroad, which resulted in an annual increase in organ supply between $5 \%$ and $25 \%$ and also helped eliminate illegal kidney purchases from other countries (Abouna 2008, 37). In 1994, 
the U.S. state of Pennsylvania approved the creation of the Organ Donor Awareness Trust Fund, which could be used to cover funeral expenses for surviving families (Ubel et al. 2000; 203). However, in 2002, the Pennsylvania Department of Health discarded the proposal, citing potential conflicts with federal law that barred the exchange of human organs for valuable consideration (Snowbeck 2002). In addition, offering health insurance benefits is another incentivizing method that has been enacted: since 2008, health insurers in the Netherlands have provided up to a $10 \%$ discount on premiums for registered donors, which equates to a reward of approximately 120 euros a year (Coppen et al. 2010, 168; Levy 2018, 415). In short, these examples illustrate the existing acceptance of various rewards and further indicate possible implementations of other incentives in the future.

\subsection{The role of money in organ donation}

\subsubsection{A market system for organ transplantation}

Arguing for a free market structure for organ transplants, Blair and Kaserman (1991) and Becker and Elías (2007) utilized a basic demand and supply model. Blair and Kaserman $(1991,415)$ pointed out that setting the organ price at zero, per the current system, would result in virtually no supply and excessive demand. With a similar approach, Becker and Elías (2007, 8-9) posited that a combination of the reducing cost of transplantation and the absence of payment for organ donors resulted in excess demand and a growing waiting list for kidney transplants. Both studies by Blair and Kaserman (1991, 425-429) and Becker and Elías (2007, 8-9) maintained that a higher equilibrium price where demand met supply would bring forth additional organs and lessen the total demand for transplants. The resulting equilibrium price would generate a net gain in social welfare, while the inelastic supply of organs would be 
reshaped into a highly elastic form. Besides this direct outcome, both studies further underlined several indirect advantages of a free market system (Blair \& Kaserman 1991, 429431; Becker \& Elías 2007, 15-21):

- Economic and health benefits from lower waiting time for transplants;

- Better tissue matching, which consequently would improve transplant quality;

- Higher use of cadaveric organ transfers and lower dependence on transplantation from living donors, a substantially more expensive and complicated process;

- Speeding up the long-term cost reduction of transplantation through a learning curve;

- Increasing acceptance of society for post-mortem organ transplantation;

- Eliminating drawbacks of organ exchanges, such as the restrictive simultaneity of transplantation, and the risks of donors' unexpected refusal;

- Eliminating illegal activities, such as price inflating in black market exchanges and organ harvesting from poor countries.

Defending the commercial aspects of market-oriented organ exchanges, Becker and Elías $(2007,21)$ brought up the legality of surrogacy in the U.S. to contend that paying for organs to save lives could not be morally weaker than paying for organs (wombs) to create lives. In the same line of argument, Jeong $(2018,20)$ posited that compensation for organ donation should be considered ethically acceptable, just as the existing payments for blood and egg donation in South Korea. In addition, Becker and Elías $(2007,21)$ highlighted that the incentive in the U.S. voluntary army and the compensation for jobs with high physical risks exemplified the legally and socially accepted commodification of human bodies. Similarly, Peters (2002, as cited in McCarrick and Darragh 2003, 59) suggested that cadaveric organ donation should be compensated for giving lives to save lives, just as a killed soldier is 
venerated with a death gratuity. In short, these studies that sought to justify the commercialization of organs focused on countering the popular view of organ sale as deeply repugnant, as noted by Radcliffe-Richards et al. (1998, 1951), and on comparing it with various lawful and widely accepted practices.

However, the commercialization of human organs is a key reason why direct payments to increase donation consent have been opposed by other researchers. Arnold et al. $(2002,1366)$ asserted that "our society does not permit its capitalistic system to operate in certain commodified exchanges because they are considered to be intrinsically wrong" and juxtaposed the sale of human organs with markets for slavery and prostitution. The authors, as well as Rothman and Rothman $(2006,6-8)$, further postulated that the sale of human organs would lead to perversion of ethical standards by removing the communal view of organ donation as altruistic, and consequently would cause those who would donate in the current system to withdraw their goodwill. Similarly, Sandel $(1998,94)$, who was further analyzed by Leonard $(2004,4)$, maintained that markets for prostitution and organ trading were “intrinsically degrading" and "morally corrupt" as they would deteriorate virtuous and civic values of society. Delmonico et al. $(2002,2004)$ also specified how altruistic acts such as organ donation constituted the fundamental values of our society and therefore allowing a poor person to risk his health for a monetary gain would severely exacerbate social integrity. As reviewed previously, the kidney exchange system in Iran indeed exemplified this major drawback of a free market: kidneys disproportionately came from poor vendors to benefit wealthy recipients (Hippen 2008, 5; Ghods \& Savaj 2006, 1141); moreover, unlike kidney donors in money-free altruistic systems who would receive positive recognition for their prosocial acts, kidney sellers in Iran experienced substantial humiliation from their own communities (Zargooshi 2001). 
Recently, Elías, Lacetera \& Macis (2019) explored an alternative to the free market system where kidney donors would be compensated by a central agency and kidneys would be distributed regardless of recipients' wealth. Such a system was supported by more than $60 \%$ of American subjects, who also found the arrangements to be ethically acceptable (Elías, Lacetera \& Macis 2019, 32). Indeed, this observation signifies the possibility to design programs that both employ the power of incentives and comply with moral standards.

\subsubsection{Funeral expense reimbursements in organ donation}

The literature in transplantation has suggested various financial inducements other than direct payments for cadaveric organ donation, most notably including tax credits, health insurance rebates for living donors and reimbursements of funeral and hospital expenses to families of deceased donors (Arnold et al. 2002, Bryce et al. 2005; Coppen et al. 2010, 167-168; Petersen \& Lippert-Rasmussen 2012; Levy 2018, 414-417). The current study focuses on incentivizing family consent with funeral aids, because of two main reasons: (1) this method has received support from academics and the public, and has been implemented in South Korea (Barnieh et al. 2012, 1959; Bryce et al. 2005, 3001-3002; Jasper et al. 2004, 382; Lee \& Kim 2009, 3554); and (2) this incentivizing instrument also allows us to develop the experimental design in the next section, focusing on the role of gifts and money in altruistic environments.

Indeed, incentivizing family consent with funeral benefits has received considerable support by medical and economic researchers. Funeral expense reimbursements were endorsed by $50 \%$ of the public, compared support of $40 \%$ and $30 \%$ for tax credits and monetary payments, respectively (Barnieh et al. 2012, 1959). Besides, Bryce et al. (2005, 3001-3002) highlighted that a funeral aid of $\$ 300$ received an $81 \%$ approval from survey respondents, especially of 
nonwhite participants, compared to a 53\% support for a 300 -dollar direct payment. The same study also found that funeral benefits would also result in higher willingness to donate or register as a donor than a direct payment. Documenting ethical evaluations of organ transplant professionals, Jasper et al. $(2004,382)$ revealed that the current altruistic system or a nonfinancial initiative to recognize donors would be the two most morally acceptable, while a $\$ 1,500$ contribution to the funeral expense was less accepted but still outperformed a health insurance discount and a direct payment of the same magnitude. The respondents in this survey further predicted that both funeral benefits and direct payments would increase organ donation the most from the current system.

Providing funeral aids to incentivize consent has also been endorsed for its ethical values. In reviewing potential incentives for cadaveric organ donation, the American Society of Transplant Surgeons panel concurred that providing funeral benefits could honor the deceased donor and convey the community's gratitude for the altruistic act (Arnold et al. 2002, 1364). Delmonico et al. $(2002,2004)$ also agreed that providing funeral benefits would depict "an expression of society's appreciation for the donation" and further posited that the funeral costs should be regarded as an expense of the donation itself. Additionally, Weale $(2011,10)$ confirmed the moral appropriateness of this incentivizing vehicle by comparing it with funeral benefits in anatomical donation for research and educational purposes. The authors further remarked that contributions to the funeral costs could be regarded as acknowledgements for the gifts of the donors. 


\section{Theoretical Framework}

A prosocial behavior is an act performed to benefit the well-being of other individuals or the integrity of society, rather than to profit the self; a prosocial behavior sometimes even requires risk or cost to the self (Brief 1986, 710; Twenge et al. 2007, 56). Organ donation, an altruistic act exclusive of any financial gains as is currently practiced in the majority of countries, exemplifies a prosocial behavior: it does not bring about any materialistic benefits for the donors or the surviving families; it increases the health risks of living donors while impairing the bodily integrity of post-mortem donors; at the same time, it saves lives and improves the health of organ recipients, and consequently promotes social integrity by ameliorating people's well-being and fortifying altruistic standards. However, when an incentive is offered for prosocial behavior, the actor now gains certain benefits, which makes the act itself no longer purely altruistic. As this is the exact condition where a direct cash payment or a funeral expense reimbursement is provided to the surviving family, it is necessary to consider how the agent's decision making might alter accordingly.

Benabou and Tirole (2006) propounded a utility function model for prosocial behavior that incorporated three sources of motivation: intrinsic, extrinsic and reputational. In the context of organ donation, these incentives would consist of agents' pure altruism (intrinsic), selfinterest in financial rewards for donating (extrinsic) and concerns about how the action is perceived by others and by themselves (reputational). The authors further suggested that changes to any of the three motivations could alter the overall meaning and the image value of altrusim, which would result in changing willingness to perform the activity. In organ donation, this result would correspond to the consideration that an incentive would deteriorate intrinsic altruism and society's positive view of organ donation, which might consequently 
discourage donation from those who would donate in a reward-free system (Arnold et al. 2002, 1366; Rothman \& Rothman 2006, 6-8). Indeed, experimental results in altruistic behaviors such as voluntary work, environmental protection, and financial trust, revealed that extrinsic monetary compensation suppressed the intrinsic selfless motivation and resulted in withdrawals of goodwill (Gneezy \& Rustichini 2000; Bowles 2008). However, there were also examples where rewards improved efforts in prosocial acts, such as the cases of financial inducements in recycling and charity donation (Kinnaman 2006, Meier 2007).

In addition, Ariely, Bracha and Meier (2009) observed that the effects of extrinsic motivation on prosocial behaviors could be determined by their visibility. Specifically, financial incentives would be more likely to encourage prosocial acts in private settings, where the image motivation had little impact on the decision. On the other hand, rewards would not be as effective in facilitating public prosocial acts: people would have lower reputational incentive, as the act could be regarded by others as mainly intended for financial gains. Organ donation would most likely be private (the anonymity of donors and recipients is even required in many jurisdictions), unless the donors or the surviving families choose to publicly announce their action (European Commission 2003, 5). Following the results of Ariely, Bracha and Meier (2009), I would expect extrinsic motivation to encourage private acts of post-mortem organ donation.

Ahn and Park's 2016 study on the effectiveness of South Korea's monetary incentive for surviving families concluded findings that partially confirmed Ariely, Bracha and Meier's 2009 results. The authors highlighted significant relations between the intention to donate and three factors: public self-consciousness (one's concern for other people's perception of himself or herself), the history of considering organ donation, and the type of reward. In 
particular, a monetary compensation, such as the one implemented in South Korea, would be more effective for those who possessed low public self-consciousness and had never considered becoming organ donors. This finding validated Ariely, Bracha and Meier's 2009 conclusion that rewards under the impact of reputational motivation would be more effective in encouraging private prosocial behaviors. However, Ahn and Park (2016, 124-125) also found that a non-monetary reward, such as an annual ceremony honoring the donor, would be more effective in achieving donation consent in individuals with high public selfconsciousness who had previously contemplated organ donation.

Moreover, the introduction of money to a money-free exchange such as organ donation could also interfere with agents' market framing. Heyman and Ariely $(2004,792)$ revealed the distinction in behaviors between a social market and a monetary market through experimental evidence: when the reward was not mentioned or was presented in the form of a gift without a specified value, effort for altruistic acts seemingly came from prosocial motivation and were unresponsive to the compensation magnitude. In these instances, the agents were in the social framing and did not consider their efforts to be work that needed to be paid for. These settings could correspond to the current altruistic organ donation system. On the other hand, Heyman and Ariely $(2004,792)$ concluded that "when payments were given in the form of cash, effort seemed to stem from reciprocation motives and was sensitive to the magnitude of the payment". Accordingly, a direct cash compensation for organ donation would likely convert the current system into a monetary market where supply would become price-sensitive. Experimental results further confirmed this activation of a monetary market as little exposure to money led people to support a free market system, in which organs could be bought from poor sellers to benefit wealthy recipients (Caruso et al. 2013). 
Incentives, such as funeral benefits, could fall in either a social market or a monetary market, depending on the visibility of the reward magnitude. In situations where agents were paid with gifts but were informed about the value, "the mere mention of monetary payment was sufficient to switch the perceived relationship from a social-market relationship to a moneymarket relationship" (Heyman \& Ariely 2004, 792). Therefore, when the surviving family is offered compensation other than a direct cash payment, but is also informed of the monetary worth, the decision maker would likely give consent to donate in a similar fashion to that under direct payments. However, Lacetera and Macis’ 2010 experiment documented somewhat contradicting findings to Heyman and Ariely (2004). Blood donors in Italy reacted divergently to different rewards: a direct payment caused previously altruistic people to withdraw their goodwill while a voucher of the same value was not met with the same reaction. Analyzing these findings, the authors highlighted the importance of how gratitude and acknowledgement, entailed in a gift but not a cash payment, were considered rewarding for the donors (Lacetera \& Macis 2010; 9). Indeed, blood donation is a context where divergent effects of rewards on altruism have been observed: surveys and framed field experiments found certain hesitance toward monetary payments for blood donation (Sanchez et al. 2001; Glynn et al. 2003; Chmielewski et al. 2012; Costa-Font, Jofre-Bonet, \& Yen 2013; Mellstrom \& Johannesson 2008; Lacetera \& Macis 2010; all as cited in Lacetera, Macis \& Slonim 2013, 927), while rewards of various kinds, including paid leave, T-shirts, coupons, lottery tickets, and gift cards, increased the probability to donate blood in natural field experiments (Lacetera \& Macis 2013; Lacetera, Macis \& Slonim 2014; Goette \& Stutzer 2020; all as cited in Lacetera, Macis \& Slonim 2013, 927). Lacetera, Macis and Slonim (2013) posited that the difference between survey and field experiments in these studies resulted in divergent effects of incentivizing. However, it also seems to be the case that cash 
payment decreased goodwill, while non-cash rewards did not cause altruistic withdrawal, or even boosted donation.

In short, studies on financial rewards in prosocial behaviors provided the necessary foundations for the examination of incentivizing family consent for cadaveric organ donation. Based on these findings, financial incentives in this context could interact with reputational values of organ donation or change the market framing of the surviving families. From varied results in existing literature, it was uncertain to predict the direction of decision making in response to incentives. The subsequent hypotheses (Section 4.5) will specify the directions this study predicts about the experimental responses based on existing literature.

\section{Factorial Survey Experiments}

\subsection{Design overview}

For this study, I constructed factorial survey designs, following the instruction of Auspurg and Hinz (2014). This experimental method is appropriate for the current study in its targets, structures and advantages. Factorial surveys illustrate vignettes, hypothetical situations with varied characteristics to inquire about normative judgements of presented scenarios. The target variables can inform researchers of "attitudes and conditions under which social norms are activated and accepted" (Auspurg \& Hinz 2014, 15). As subsequently specified in 4.2.2, these elements are exactly what this study aims to capture: ethical appraisals and willingness to provide consent for post-mortem organ donation under different incentives.

Moreover, factorial surveys feature the advantages of both experiments and traditional surveys. Randomization of hypothetical scenarios to subjects in an experiment is sufficient to 
ensure internal validity. On the other hand, survey research can be flexibly utilized for homogeneous groups, enhancing its external application. Hypothetical dimensions in a factorial design further allow researchers to examine rare situations, which might have other highly correlated elements in reality (Auspurg \& Hinz 2014, 12-13). All of these points are valid for the current study. Being asked for cadaveric donation consent as part of a surviving family is certainly not a common experience people have gone through. For example, Organ Procurement \& Transplantation Network (2021) documented 236,645 deceased donors since 1988. If there were about the same number of surviving families who had gone through the experience, this projection would still account for less than $1 \%$ of the total number of households in the United States (U.S. Census Bureau 2019). Therefore, surveying using randomized vignettes in an unspoiled subject pool would circumvent problems with highly correlated factors specific to this experience in reality, as noted in Section 2.1. Lastly, the interpretability of the results is a major goal for this study, as it can elucidate academics and policymakers on the efficacy of incentivizing family consent for post-mortem donation. A survey research would offer this benefit as it is flexible enough to be carried out for a more diverse subject group.

\subsection{Variables of interest}

This study is divided into two major themes: (1) the relationship between incentivizing and ethical judgments: how individuals discern different rewards in their moral values, and (2) the relationship between incentivizing and decision making: how individuals' willingness to consent for post-mortem donation changes under different rewards. 


\subsubsection{Exogenous variables and treatments}

The main explanatory variables in this study were constructed based on Heyman and Ariely's results of market framing (2004). As reviewed in Section 3.1, the authors characterized market framing for prosocial acts into three categories: a social market, a monetary market, and a mixed market combining elements of the other two. Accordingly, I developed the following rewards that corresponded to the three market structures and varied magnitude:

- No donation incentive (Control)

- A full funeral service without specified monetary value (Gift-high)

- A funeral casket without specified monetary value (Gift-low)

- A full funeral service worth $\$ 7,500$ (\$Gift-high)

- A funeral casket worth $\$ 2,500$ (\$Gift-low)

- A $\$ 7,500$ direct payment (Cash-high)

- A $\$ 2,500$ direct payment (Cash-low)

The social market structure defined by Heyman and Ariely $(2004,787)$ would include the first three groups above. Individuals in the control group would see all factorial dimensions about a hypothetical situation, and were directly asked to indicate their willingness to consent. In the two Gift groups, when a gift reward was offered but no value was mentioned, individuals would stay in the social market mindframe. The $\$$ Gift groups would correspond to a mixed market with both social and monetary properties, while participants in the Cash groups would be in a purely monetary market (Heyman \& Ariely 2004, 787).

Utilizing these treatment and control groups, I took several precautions in the vignette delivery. Firstly, the wording for the Gift and \$Gift groups clearly outlined that the compensations were gift rewards for altruistic acts. Furthermore, because of the sentimental 
nature of the hypothetical situation, the information had to be presented carefully so as not to appear offensive or insensitive. In addition, the phrasing was fashioned to ensure participants' understanding that the rewards would benefit themselves, instead of a vaguely defined "surviving family." To accomplish this goal, I specified that the subject would be the one paying for the funeral service of the deceased in the Gift and \$Gift treatments. In the Cash group, I remarked that subjects would be the hypothetical recipients of the payments. The exact phrasing for the rewards is shown in Table A.4.2-1.

The compensation choices related to funeral services stemmed from suggestions of funeral expense reimbursement in the literature for its ethical values and from the actual implementation in South Korea (Arnold et al. 2002, 1363; Lee \& Kim 2009, 3554). In this study, however, I reframed this incentivizing method from a reimbursement, which had a clear notion of money, to a gift reward: an honorary casket or a full funeral service. Proposing a full funeral service as the high-level reward in the gift treatments, I clarified that the reward would include all funeral facilities, equipment and professional services. Choosing an appropriate gift of low magnitude in this context was also challenging: a funeral service in the US mostly consists of human tasks, while gift rewards in behavioral literature were often physical objects (National Funeral Directors Association 2017; Kube, Marechal Puppe, 2012; Prendergast \& Stole 2001; Heyman \& Ariel 2004). Of the different components in a funeral service, the casket would work as a gift in this study for several reasons: (1) a casket is a physical object, and thus is more suitable to be presented as a gift than the professional services performed in a funeral; (2) caskets are used in both burial and cremation and thus is mandatory for a funeral service (National Funeral Directors Association 2017); (3) a casket's cost, averaging $\$ 2,400$, was substantial, yet accounted for only a minority portion of the overall cost, averaging \$7,360 (National Funeral Directors Association 2017). This cost ratio 
allowed us to construct the two levels of incentivizing: a low reward with a 2,500-dollar casket and a high reward with a 7,500-dollar full funeral service. The numbers were rounded up for presentational purposes, as well as to reflect expectedly higher prices currently than in 2017. Furthermore, when compared to South Korea’s $\$ 4,500$ compensation for funeral expenses, the two numbers represented two opposing reward levels.

Sociodemographic controls in the subsequent regression covered the subject's age, gender, ethnicity, religion, education attainment, income, employment status and organ donation status. Particular to the current study, organ donation status was included in the model as it was found significant in responses to incentives in Ahn and Park's 2016 study. This variable contained three categories: "registered," "not registered but have considered," and "not registered and have never considered."

\subsubsection{Endogenous variables}

The 2002 panel of American academics and experts in organ transplantation suggested that an incentive for organ donation needed to satisfy various ethical principles (Arnold et al. 2002, 1363). These criteria provided the bases to design seven moral judgment questions in the survey, namely (1) keeping the notion of donated organ as gifts, (2) expressing gratitude, (3) honoring the deceased, (4) preserving voluntariness, (5) maintaining altruistic standards, (6) avoiding facilitation of "a slippery slope" to sales of human organs, and (7) preserving society's positive perception of organ donation. Of the two remaining criteria by Arnold et al. that were not covered $(2002,1363)$, that an incentive should not intrude the human body without permission is irrelevant in the study, as all treatments specifically asked subjects about their consent for organ transfer. On the other hand, that an incentive "should not be an 
excessive inducement that would undermine personal values and alter decision-making solely to receive the compensation" (Arnold et al. 2002, 1363) would be part of the primary examination of compensation magnitude's impact on WTC. In particular, a low-reward level of $\$ 2,500$ would fall in the range of an acceptable reimbursement amount, while the highreward level of $\$ 7,500$ would be considered excessive (Arnold et al. 2002, 1366).

For each question, subjects were asked to indicate their positions relative to two opposite statements on a rating scale from 5 (strongly agree with the positive Statement A) to -5 (strongly agree with the negative Statement B). For example, regarding whether an incentive honored the donor, the question was phrased as follows:

How would you place your judgment with regard to the below pair of opposite statements:

- Statement A: "This initiative would greatly honor the deceased donor"

- Statement B: "This initiative would seriously dishonor the deceased donor"

The presentation of both positive and negative statements was employed to eliminate potential issues with phrasing (Roszkowski \& Soven 2000), as also employed by Elías et al. (2019). The exact wording of all questions could be found in Table A.4.2-2.

In the second topic, the dependent variable was the willingness to give family consent (WTC) for post-mortem donation. The design of this question, as well as all treatments and control, was equivalent to Heyman and Ariely's Experiment $1(2004,789)$, in which individuals were asked to indicate their willingness to provide assistance. The responses in this question would help evaluate the central question: what is the most effective method of incentivizing WTC?

Lastly, in all inquiries of normative judgments, I employed the rating scales with eleven categories. The scale example in Figure A.4.2-1 was used in ethical evaluation questions. For 
the WTC question, the explanation texts for $-5,0$ and 5 were respectively "Extremely unlikely," "Neither likely nor unlikely," and "Extremely likely" (see Figure A.4.2-2). Auspurg and Hinz $(2014,64-70)$ recommended this scale for factorial surveys, as it provided both usability for respondents and convenience for surveyors. In this 11-point scale with 10 intervals, a change of one point can be directly translated to a $10 \%$ difference.

\subsection{Design specifications}

\section{a. Specifications of dimensions and levels}

The factorial survey experiment was specified with 5 dimensions, an appropriate number recommended by Auspurg and Hinz $(2014,22)$. Table A.4.3-1 summarizes the vignette dimensions that were offered to participants. The potential donor's age, gender, death type and wish to donate were chosen as they were shown to influence the surviving family's decision to allow transplantation (Section 2.1). To facilitate credible vignettes, the survey presented subjects with situations regarding a hypothetical brother or sister, instead of just vaguely worded male or female relatives. To simplify the factorial design, family relationship was not utilized with other levels, as it was not found in the literature to have significant impact on family consent (see Section 2.1). The deceased's age was shown in 3 levels $(25,40$ and 55), representing the age range of a majority of American organ donors (Statista 2021). Only one validation was employed to increase vignette believability: older subjects would not see scenarios of 25-year-old siblings, while younger subjects were not shown vignettes of 55year-old siblings. Brain death and circulatory death were the two levels of death type. The hypothetical deceased's existing wish to become a donor after death was shown as either yes, 
no or unclear. Lastly, the reward dimension had seven levels, representing the control and six treatments of varying types and magnitudes.

To engage and familiarize participants in the hypothetical environment, the vignette dimensions slowly appeared in a storyline format rather than shown all at once (see Table A.4.3-2). The order of these vignettes is intended to emulate a realistic order of events: an individual was at a hospital and approached by a doctor about news of a family member (Screen 1); the death of the sibling was announced, and the question of organ donation was brought up (Screen 2); the subject was reminded of the sibling's existing wish to become a donor after death (Screen 3). Timing validations, which temporarily disabled the option to move forward, were also implemented to ensure subjects' attentiveness.

In addition, the design employed several measures to increase the credibility of the factorial survey setup. To emulate a common practice to ensure the surviving family's understanding of brain death criteria (Franz et al. 1997), the vignettes provided a brief definition of the type of death (brain or circulatory) and further specified that a patient with either death type was legally and clinically dead. When the donation question was brought up, the vignette also emphasized that the subject was the decision maker and had the hypothetical right to give permission for organ donation after death. Lastly, the subject was informed that the donation would save the lives or improve the well-being of several waiting patients, which was also a very common conversation topic in practice (Siminoff et al. 2001, 75). Indeed, there would be other issues to be discussed with the surviving family when the donation question was asked. However, the reminder that the donation would help others was intended to put the subject into the mindset of performing an altruistic act (Yang, Hsee \& Urminsky 2014).

Readers can consult Table A.4.3-2 for a summary of all stages in the experiment flow. 


\section{b. Full factorial design}

The study is a $3^{2} 2^{2} 7$ design, resulting in a total of 252 unique vignettes $\left(3^{2} 2^{2} 6=216\right.$ in the ethical evaluation study). As this number is manageable in the data collection, the survey was conducted as a full factorial design, which entails that the experimental units captured all possible level combinations across dimensions. Furthermore, the Qualtrics survey randomly presented vignettes to participants, but was designed to sample each vignette exactly 3 times $(n=756)$. As a result, this method ensured the balance of the study and the strength of the coefficients (Auspurg \& Hinz 2014, 16).

\subsection{Econometric models}

Auspurg and Hinz $(2014,99)$ confirmed that OLS was appropriate for analyzing factorial survey data. From the generalized model for factorial surveys (Auspurg \& Hinz 2014, 88), I formulated the following models for the tests of ethical appraisal and willingness to consent:

ethical $_{j}=\alpha+\beta_{1}$ rewards $_{j}+\beta_{2}$ wish $_{j}+\beta_{3}$ deathtype $_{j}+\beta_{4}$ age $_{j}+\beta_{5}$ gender $_{j}+\gamma Z_{j}+u_{j}$ $W T C_{j}=\alpha+\beta_{1}$ rewards $_{j}+\beta_{2}$ wish $_{j}+\beta_{3}$ deathtype $_{j}+\beta_{4}$ age $_{j}+\beta_{5}$ gender $_{j}+\gamma \boldsymbol{Z}_{j}+u_{j}$ with $j=1, \ldots, n$ (index for individual respondent)

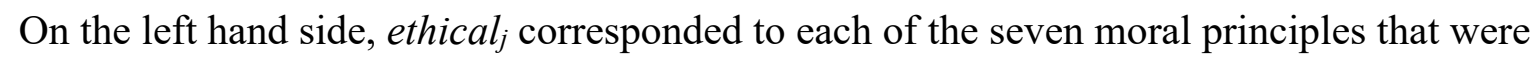
specified in Section 4.2.2. In the second model, $W T C_{j}$ delineated respondents' willingness to consent for post-mortem organ donation. Both dependent variables are measured on an eleven scale. The first exogenous variable reward indicated six treatment conditions in the first equation and seven conditions including the control in the second. The six distinct rewards 
varied in whether they were presented as gifts, whether they were attached with monetary worth, and whether the reward magnitude was low or high.

In both models, the remaining vignette-level variables included knowledge of the deceased's wish to donate after death, the type of death, and the deceased's age and gender. $Z_{j}$ represented all respondent-level variables, which contained age, gender, race, religion, education, employment status, income and history of considering organ donation. The beta coefficients $\left(\beta_{1}\right.$ to $\left.\beta_{5}\right)$ measured the effects of vignette dimensions, while the generalized $\gamma$ denoted coefficients for all sociodemographic variables. Per the experimental design, each subject was only presented with one vignette, so there were no longer vignette variations for each subject. Accordingly, there was only a subject-specific error term $u_{j}$ in the model while the error component regarding vignette-subject variations $\varepsilon_{i t}$ was eliminated.

\subsection{Hypotheses}

\section{a. Main hypotheses}

Following Arnold et al.'s 2002 evaluation, I hypothesized that funeral benefits would be perceived to be more morally appropriate than a direct cash compensation. Furthermore, when a gift reward was accompanied by its monetary value, subjects would react to it similarly to a direct payment (Heyman \& Ariely 2004). A low compensation would further be considered more ethically appropriate than a high compensation of the same reward type (Arnold et al. 2002, 1366). In short, the first hypothesis could be collectively stated as follows:

Hypothesis 1: Different reward conditions lead to different judgments of their ethical values. 
Heyman and Ariely (2004) highlighted that dissimilar framing of market relationships led to substantially different willingness to perform prosocial acts. Employing these findings, I formulated the hypotheses based on the authors' Hypotheses 1, 1a, $1 \mathrm{~b}$ and $2(2004,788)$ :

Hypothesis 2.1: Different reward conditions lead to different willingness to give family consent for organ donation.

Hypothesis 2.2: The relationship between reward magnitude and WTC is different between social markets and markets with notions of money, in particular:

- Hypothesis 2.2.a: In Gift treatments, different reward magnitudes do not lead to different levels of WTC.

- Hypothesis 2.2.b: In \$Gift and Cash treatments, different reward magnitudes lead to different levels of WTC.

Hypothesis 2.2, 2.2.a and 2.2.b focus on decision making in different market framing with regards to the notion of money (Heyman and Ariely 2004, 787). Both Experiments 1 and 2 by Heymand and Ariely (2004) revealed no significant differences in hypothetical willingness to help and actual effort between three levels of payment: no rewards, low rewards and high rewards with no revealed value. In the current context, these social markets correspond to two cases: the control group and the two Gift treatments with funeral benefits unaccompanied by monetary notion. The effects of gifts on decision making in the Gift groups were captured in Hypothesis 2.2.a. Besides, Hypothesis 2.2.b deals with responses in markets with specifications of financial values: the monetary market with compensations for efforts and the mixed market where actors receive gift rewards that were accompanied by their monetary values (Heyman and Ariely 2004, 787). Accordingly, these two markets in this study are accordingly the Cash treatments for the former and the $\$$ Gift treatments for the latter. 


\section{b. Supplementary hypotheses}

As analyzed in Section 2.1, donation decisions could be shaped by many factors specific to the occasion, including the surviving family's acceptance of brain death criteria, age and gender of the deceased, the knowledge of the deceased's wish. These elements were indeed addressed in the survey design in Section 4.3, and thus their associations with ethical evaluations and the donation decision would need to be examined in the analysis. Accordingly, I constructed the following collective hypotheses, in which vignette elements would correspond to variables wish, deathtype, age-donor and gender-donor in the econometric models.

Hypothesis 3.1.a: Vignette elements lead to different levels of moral judgments for incentives.

Hypothesis 3.2.a: Vignette elements lead to different levels of WTC.

As reviewed in Section 2.1.c, ethnic and religious backgrounds of surviving families were found to have significant associations with organ donation consent (Barber et al. 2006; Ghorbani et al. 2011; Mojtabaee et al. 2018; Mithra et al. 2013). Therefore, the study will also investigate the links between WTC and respondents' sociodemographic backgrounds $\boldsymbol{Z}$ in the models. The supplementary hypothesis is specified as follows:

Hypothesis 3.1.b: Sociodemographic factors lead to different levels of moral judgments.

Hypothesis 3.2.b: Sociodemographic factors lead to different levels of WTC. 


\subsection{Subject pool}

Existing studies in post-mortem donation mainly focused on families who had gone through the experience (Siminoff et al. 2001; Rodrigue et al. 2006; Sque at al. 2008; Mojtabaee et al. 2018). However, from Auspurg and Hinz (2004, 12-13), post-mortem organ donation could be an example of an occurrence where many highly correlated factors existed, and thus, utilizing a factorial survey with hypothetical situations would help eliminate potential biases. As the factorial design centered on highly detailed vignettes, it was crucial that the subjects paid close attention throughout the study; this was shown to be the particular strength of MTurk, leading to my decision to conduct the study with MTurk worker subjects (Weinberg, Freese \& McElhattan 2014; Hauser \& Schwarz 2016).

In addition, economic experiments on financial incentives in organ donation have also acknowledged the potential bias in using a younger student pool to interpret the general population's behavior (Frank Adams III et al. 1999, 150; Altinanahtar, Crooker \& Kruse, 2008, 8). Employing MTurk could mitigate this issue: the MTurk worker base was found to be closer of the general population in age, gender, race, education attainment (Burnham, Le \& Piedmont 2018), as well as in psychological and ideological dimensions (McCredie \& Morey 2018; Clifford, Jewell \& Waggoner, 2015). On the other hand, one particular concern with employing Mechanical Turk was regarding the participants' religious affiliation. Organ donation literature recorded that religious views, particularly Islamic faiths, could strongly influence cadaveric organ donation refusal (Ghorbani et al. 2011; Mojtabaee et al. 2018; Mithra et al. 2013). Burnham et al. (2018) revealed that MTurk had a disproportionately high number of agnostic and atheist workers compared to the general US population. 
The experiment was conducted in January 2021. The responses came from 756 U.S.-based respondents. Readers can see Table A.4.6 in the Appendix, which summarizes main characteristics of the participants and the U.S. population. The MTurk respondents appeared similar to the population in median income, percentage of white residents and percentage of followers of non-Christian religions, but had slightly more young and female surveyees than the population. As expected, there were also more agnostics and atheists, and fewer Christians among the respondents.

I limited the survey availability to only participants located in the United States for several reasons. Firstly, this survey design would be best applied for respondents in the same country. As reviewed in Section 2.2, transplantation laws and practices varied greatly across jurisdictions. The incentives were further attached to the expense of funeral services, which was likely to vary across countries. Therefore, US-based workers, representing $75 \%$ of the platform, were selected (Difallah, Filatova \& Ipeirotis 2018, 138).

\section{Results and Analysis}

\subsection{Ethical evaluation of incentivizing methods}

Tables 5.1-1 and 5.1-2 display the regression results of subjects' moral appraisals for the six incentivizes with robust standard errors. Remarkably, the four Gift and \$Gift reward schemes strongly outperformed the $\$ 7,500$ direct payment in all seven moral principles, most of which were even significant at P-value $<0.01$. The two Gift incentives, a full funeral service or an honorary casket without revealed monetary worth, appeared to increase ethical values the most from the high cash reward. In particular, a full funeral service was perceived $24.8 \%$ better in keeping away organ commercialization than a $\$ 7,500$ payment, while the honorary 
casket incentive was $22.7 \%$ better in maintaining organ donation as gifts to recipients than the high cash reward. The two monetized $\$$ Gift schemes were also significantly better judged than the $\$ 7,500$ payment in all principles, though the effects seemed slightly smaller than the corresponding Gift rewards in most categories. For example, in conveying gratitude for the donation, a $\$ 7,500$ full funeral and a $\$ 2,500$ casket were judged respectively $13.3 \%$ and $11.3 \%$ higher than a $\$ 7,500$ payment, compared to increases of $16.5 \%$ for a full funeral and $13.2 \%$ for a casket unaccompanied by value. However, in maintaining society's positive view of organ donation, the two monetized funeral aids would improve moral values the most from a high cash reward, with increases of above $15 \%$. Lastly, unlike the funeral benefit incentives, a low payment of $\$ 2,500$ did not appear to be perceived significantly different from a high cash prize.

As the regression results only provided comparison among the individual rewards, Table 5.13 further showed subsequent contrast analyses that juxtaposed specific pairs of incentivizing schemes. Gift rewards in the form of funeral benefits, whether coupled with monetary worth or not, were significantly better judged in all ethical principles, with improvements ranging from $11.5 \%$ in conveying gratitude to $19.4 \%$ in shunning organ commercialization. The two Gift rewards unaccompanied by monetary worth were also significantly better evaluated than the four monetized rewards (\$Gift and Cash); the effect size, however, appeared smaller than the prior contrasts, with the highest increase of $11.9 \%$ in keeping away commercialization. The link between reward magnitude and moral values was not significant in most principles, except for in honoring the donor, where low rewards were judged $4.8 \%$ lower than high rewards. 
Overall, the results that funeral benefits outperformed cash payments in all normative principles further confirmed the findings in previous studies tracked in Section 2.3.2 (Arnold et al. 2002, Jasper et al. 2004; Bryce et al. 2005; Coppen et al. 2010, 167-168; Levy 2018).

\subsection{Consent under different methods of incentivizing}

Table 5.2-1 illustrates the regression results with robust standard errors for the willingness to provide family consent (WTC). Most notably, the coefficients were significant for a full funeral service without a revealed value. This incentivizing vehicle would improve the willingness to allow organ donation $8.5 \%$ compared to the control representing the current reward-free system $(\mathrm{P}$-value $<0.05$ ). With weak significance, a full funeral worth $\$ 7,500$ would also increase consent from the control by $7.8 \%$ (P-value $<0.1)$.

Table 5.2-2 further provides contrasts between specific pairs of rewards regarding their impact on WTC. In particular, funeral aids with and without revealed worth would significantly improve consent giving by $8.3 \%$ compared to direct payments ( $\mathrm{P}$-value $<0.01$ ). Moreover, funeral benefits without mentioned value weakly outperformed monetized rewards altogether by $4.2 \%$ (P-value $<0.1)$. No statistical significance, however, was found between rewards of different magnitudes. In Figure 5.2, which visualizes the predicted WTC for each incentive with $95 \%$ confidence intervals, there seems to be a slight trend of price sensitivity between low and high rewards, especially among cash prizes. However, since contrast analyses did not find significant differences associated with reward magnitude, we could only confirm the existence of a social market for Gift rewards (Hypothesis 2.2a) while not having enough evidence to conclude the existence of a monetary market for \$Gift and Cash prizes (Hypothesis 2.2.b). 
Table 5.1-1 Regression results of ethical evaluations (1 to 4)

\begin{tabular}{|c|c|c|c|c|}
\hline & $\begin{array}{l}\text { Maintain OD } \\
\text { as gifts }\end{array}$ & $\begin{array}{l}\text { Convey } \\
\text { gratitude }\end{array}$ & $\begin{array}{l}\text { Honor the } \\
\text { donor }\end{array}$ & $\begin{array}{l}\text { Preserve } \\
\text { voluntariness }\end{array}$ \\
\hline \multicolumn{5}{|c|}{ Incentive (vs. $\$ 7,500$ cash - Cash-high) } \\
\hline $\begin{array}{l}\$ 2,500 \text { cash (Cash- } \\
\text { low) }\end{array}$ & $\begin{array}{l}0.884^{*} \\
(0.472)\end{array}$ & $\begin{array}{l}0.419 \\
(0.398)\end{array}$ & $\begin{array}{l}-0.083 \\
(0.442)\end{array}$ & $\begin{array}{l}-0.225 \\
(0.504)\end{array}$ \\
\hline $\begin{array}{l}\text { Full funeral } \\
\text { (Gift-high) }\end{array}$ & $\begin{array}{l}2.161^{* * *} \\
(0.467)\end{array}$ & $\begin{array}{l}1.651 * * * \\
(0.360)\end{array}$ & $\begin{array}{l}1.875 * * * \\
(0.423)\end{array}$ & $\begin{array}{l}1.635^{* * *} \\
(0.478)\end{array}$ \\
\hline $\begin{array}{l}\text { Casket } \\
\text { (Gift-low) }\end{array}$ & $\begin{array}{l}2.269 * * * \\
(0.464)\end{array}$ & $\begin{array}{l}1.321 * * * \\
(0.368)\end{array}$ & $\begin{array}{l}0.931 * * \\
(0.431)\end{array}$ & $\begin{array}{l}1.646 * * * \\
(0.479)\end{array}$ \\
\hline $\begin{array}{l}\$ 7,500 \text { full funeral } \\
\text { (\$Gift-high) }\end{array}$ & $\begin{array}{l}1.881^{* * *} \\
(0.479)\end{array}$ & $\begin{array}{l}1.329 * * * \\
(0.386)\end{array}$ & $\begin{array}{l}1.576 * * * \\
(0.427)\end{array}$ & $\begin{array}{l}1.392^{* * *} \\
(0.476)\end{array}$ \\
\hline $\begin{array}{l}\$ 2,500 \text { casket } \\
\text { (\$Gift-low) }\end{array}$ & $\begin{array}{l}1.771 * * * \\
(0.471)\end{array}$ & $\begin{array}{l}1.125 * * * \\
(0.385)\end{array}$ & $\begin{array}{l}1.138 * * * \\
(0.429)\end{array}$ & $\begin{array}{l}1.662^{* * *} \\
(0.461)\end{array}$ \\
\hline \multicolumn{5}{|c|}{ Wish to donate (vs. yes) } \\
\hline No & $\begin{array}{l}-1.014^{* * *} \\
(0.332)\end{array}$ & $\begin{array}{l}-0.725 * * * \\
(0.255)\end{array}$ & $\begin{array}{l}-2.673 * * * \\
(0.300)\end{array}$ & $\begin{array}{l}-1.242^{* * *} \\
(0.324)\end{array}$ \\
\hline Unclear & $\begin{array}{l}0.057 \\
(0.314)\end{array}$ & $\begin{array}{l}0.097 \\
(0.234)\end{array}$ & $\begin{array}{l}-0.311 \\
(0.264)\end{array}$ & $\begin{array}{l}0.021 \\
(0.318)\end{array}$ \\
\hline \multicolumn{5}{|c|}{ Donor's age (vs. 25 years old) } \\
\hline 40 years old & $\begin{array}{l}0.056 \\
(0.340)\end{array}$ & $\begin{array}{l}0.351 \\
(0.270)\end{array}$ & $\begin{array}{l}0.111 \\
(0.319)\end{array}$ & $\begin{array}{l}0.123 \\
(0.351)\end{array}$ \\
\hline 55 years old & $\begin{array}{l}0.156 \\
(0.416)\end{array}$ & $\begin{array}{l}-0.072 \\
(0.331)\end{array}$ & $\begin{array}{l}-0.365 \\
(0.369)\end{array}$ & $\begin{array}{l}0.165 \\
(0.423)\end{array}$ \\
\hline Brain death & $\begin{array}{l}-0.095 \\
(0.256)\end{array}$ & $\begin{array}{l}-0.041 \\
(0.204)\end{array}$ & $\begin{array}{l}0.179 \\
(0.236)\end{array}$ & $\begin{array}{l}-0.073 \\
(0.263)\end{array}$ \\
\hline Female donor & $\begin{array}{l}-0.157 \\
(0.269)\end{array}$ & $\begin{array}{l}-0.297 \\
(0.201)\end{array}$ & $\begin{array}{l}0.065 \\
(0.233)\end{array}$ & $\begin{array}{l}-0.520 * \\
(0.267)\end{array}$ \\
\hline Constant & $\begin{array}{l}0.516 \\
(1.033)\end{array}$ & $\begin{array}{l}2.043 * * \\
(0.845)\end{array}$ & $\begin{array}{l}1.280 \\
(0.912)\end{array}$ & $\begin{array}{l}-0.240 \\
(0.977)\end{array}$ \\
\hline Vignettes & 216 & 216 & 216 & 216 \\
\hline Observations & 648 & 648 & 648 & 648 \\
\hline $\mathrm{R}^{2}$ & 0.142 & 0.144 & 0.218 & 0.135 \\
\hline
\end{tabular}

Note: robust standard errors in parentheses; ${ }^{* * *} p<0.01,{ }^{* *} p<0.05,{ }^{*} p<0.1$ 
Table 5.1-2 Regression results of ethical evaluations (5 to 7)

\begin{tabular}{|c|c|c|c|}
\hline & $\begin{array}{l}\text { Not equivalent } \\
\text { to organ sale }\end{array}$ & $\begin{array}{l}\text { Preserve altruistic } \\
\text { standards }\end{array}$ & $\begin{array}{l}\text { Maintain positive } \\
\text { view of society }\end{array}$ \\
\hline \multicolumn{4}{|c|}{ Incentive (vs. $\$ 7,500$ cash - Cash-high) } \\
\hline $\begin{array}{l}\$ 2,500 \text { cash } \\
\text { (Cash-low) }\end{array}$ & $\begin{array}{l}0.457 \\
(0.456)\end{array}$ & $\begin{array}{l}0.427 \\
(0.444)\end{array}$ & $\begin{array}{l}-0.101 \\
(0.416)\end{array}$ \\
\hline $\begin{array}{l}\text { Full funeral } \\
\text { (Gift-high) }\end{array}$ & $\begin{array}{l}2.480^{* * *} \\
(0.442)\end{array}$ & $\begin{array}{l}2.037^{* * *} \\
(0.420)\end{array}$ & $\begin{array}{l}1.320^{* * *} \\
(0.379)\end{array}$ \\
\hline $\begin{array}{l}\text { Casket } \\
\text { (Gift-low) }\end{array}$ & $\begin{array}{l}2.149^{* * *} \\
(0.455)\end{array}$ & $\begin{array}{l}1.951^{* * *} \\
(0.439)\end{array}$ & $\begin{array}{l}1.243^{* * *} \\
(0.375)\end{array}$ \\
\hline $\begin{array}{l}\$ 7,500 \text { full funeral } \\
\text { (\$Gift-high) }\end{array}$ & $\begin{array}{l}2.251^{* * *} \\
(0.456)\end{array}$ & $\begin{array}{l}1.928^{* * *} \\
(0.448)\end{array}$ & $\begin{array}{l}1.518^{* * *} \\
(0.380)\end{array}$ \\
\hline $\begin{array}{l}\$ 2,500 \text { casket } \\
\text { (\$Gift-low) }\end{array}$ & $\begin{array}{l}1.778^{* * *} \\
(0.462)\end{array}$ & $\begin{array}{l}1.701^{* * *} \\
(0.429)\end{array}$ & $\begin{array}{l}1.578^{* * *} \\
(0.364)\end{array}$ \\
\hline \multicolumn{4}{|c|}{ Wish to donate (vs. yes) } \\
\hline No & $\begin{array}{l}-1.287^{* * *} \\
(0.310)\end{array}$ & $\begin{array}{l}-1.424^{* * *} \\
(0.293)\end{array}$ & $\begin{array}{l}-1.219^{* * *} \\
(0.260)\end{array}$ \\
\hline Unclear & $\begin{array}{l}-0.126 \\
(0.310)\end{array}$ & $\begin{array}{l}-0.302 \\
(0.295)\end{array}$ & $\begin{array}{l}-0.182 \\
(0.248)\end{array}$ \\
\hline \multicolumn{4}{|c|}{ Donor's age (vs. 25 years old) } \\
\hline 40 years old & $\begin{array}{l}-0.147 \\
(0.334)\end{array}$ & $\begin{array}{l}-0.105 \\
(0.319)\end{array}$ & $\begin{array}{l}-0.228 \\
(0.287)\end{array}$ \\
\hline 55 years old & $\begin{array}{l}-0.407 \\
(0.403)\end{array}$ & $\begin{array}{l}-0.313 \\
(0.386)\end{array}$ & $\begin{array}{l}-0.326 \\
(0.335)\end{array}$ \\
\hline Brain death & $\begin{array}{l}-0.110 \\
(0.254)\end{array}$ & $\begin{array}{l}-0.192 \\
(0.240)\end{array}$ & $\begin{array}{l}-0.191 \\
(0.208)\end{array}$ \\
\hline Female donor & $\begin{array}{l}-0.305 \\
(0.254)\end{array}$ & $\begin{array}{l}-0.396^{*} \\
(0.239)\end{array}$ & $\begin{array}{l}-0.188 \\
(0.210)\end{array}$ \\
\hline Constant & $\begin{array}{l}-0.838 \\
(0.976)\end{array}$ & $\begin{array}{l}-1.218 \\
(0.969)\end{array}$ & $\begin{array}{l}0.936 \\
(0.835)\end{array}$ \\
\hline Vignettes & 216 & 216 & 216 \\
\hline Observations & 648 & 648 & 648 \\
\hline $\mathrm{R}^{2}$ & 0.186 & 0.161 & 0.150 \\
\hline
\end{tabular}

Note: robust standard errors in parentheses; ${ }^{* * *} p<0.01,{ }^{* *} p<0.05,{ }^{*} p<0.1$ 
Table 5.1-3 Contrast analyses on selected pairs of rewards on ethical evaluation

\begin{tabular}{llll}
\hline & $\begin{array}{l}\text { Gift labeling: } \\
\text { (Gift \& \$Gift) vs. Cash }\end{array}$ & $\begin{array}{l}\text { Notion of money: } \\
\text { Gift vs. (\$Gift \& Cash) }\end{array}$ & $\begin{array}{l}\text { Reward magnitude: } \\
\text { Low vs. high rewards }\end{array}$ \\
\hline Maintain OD & $1.579^{* * *}$ & $1.081^{* * *}$ & 0.291 \\
as gifts & $(0.284)$ & $(0.267)$ & $(0.254)$ \\
Convey & $1.147^{* * *}$ & $0.768^{* * *}$ & -0.038 \\
gratitude & $(0.235)$ & $(0.198)$ & $(0.199)$ \\
Honor & $1.421^{* * *}$ & $0.745^{* * *}$ & $-0.484^{* *}$ \\
the donor & $(0.263)$ & $(0.242)$ & $(0.230)$ \\
Preserve & $1.696^{* * *}$ & $0.933^{* * *}$ & 0.184 \\
voluntariness & $(0.294)$ & $(0.273)$ & $(0.256)$ \\
Not equivalent & $1.936^{* * *}$ & $1.193^{* * *}$ & -0.115 \\
to sale & $(0.275)$ & $(0.258)$ & $(0.247)$ \\
Keep altruistic & $1.691^{* * *}$ & $0.980^{* * *}$ & 0.037 \\
standards & $(0.263)$ & $(0.245)$ & $(0.234)$ \\
Keep society's & $1.465^{* * *}$ & $0.532^{* *}$ & -0.039 \\
positive view & $(0.242)$ & $(0.216)$ & $(0.211)$ \\
\hline
\end{tabular}

Note: robust standard errors in parentheses; ${ }^{* * *} p<0.01,{ }^{* *} p<0.05,{ }^{*} p<0.1$

Table 5.2-1 Regression results of willingness to consent (WTC)

\begin{tabular}{llll}
\hline & WTC & & \multicolumn{2}{l}{ WTC } \\
\hline Incentive (vs. Control) & & \multicolumn{2}{l}{ Wish to donate (vs. yes) } \\
\$7,500 cash & 0.148 & No & $-4.707^{* * *}$ \\
(Cash-high) & $(0.401)$ & & $(0.282)$ \\
\$2,500 cash & -0.451 & Unclear & $-0.977^{* * *}$ \\
(Cash-low) & $(0.445)$ & & $(0.217)$ \\
Full funeral & $0.848^{* *}$ & & \\
(Gift-high) & $(0.399)$ & Donor's age (vs. 25 years old) \\
Casket & 0.509 & 40 years old & 0.420 \\
(Gift-low) & $(0.413)$ & & $(0.305)$ \\
\$7,500 full funeral & $0.787^{*}$ & 55 years old & 0.259 \\
(\$Gift-high) & $(0.401)$ & & $(0.354)$ \\
\$2,500 casket & 0.564 & Brain death & 0.035 \\
(\$Gift-low) & $(0.391)$ & & $(0.221)$ \\
Constant & $2.018^{* *}$ & Female donor & -0.020 \\
& $(0.923)$ & & $(0.219)$ \\
\hline Vignettes & 252 & Observations & 756 \\
R $^{2}$ & 0.403 & & \\
\hline
\end{tabular}

Note: robust standard errors in parentheses; ${ }^{* * *} p<0.01,{ }^{* *} p<0.05,{ }^{*} p<0.1$ 
Table 5.2-2 Contrast analyses on selected pairs of rewards and their impact on WTC

\begin{tabular}{llll}
\multicolumn{1}{c}{$\begin{array}{l}\text { Contrast } \\
\text { (std. error) }\end{array}$} & & $\begin{array}{l}\text { Contrast } \\
\text { (std. error) }\end{array}$ \\
\hline (Gift \& \$Gift) vs Cash & $\begin{array}{l}0.828^{* * *} \\
(0.255)\end{array}$ & Gift-low vs Gift-high & -0.169 \\
& $0.416^{*}$ & \$Gift-low vs \$Gift-high & $-0.200)$ \\
Gift vs (\$Gift \& Cash) & $(0.248)$ & & $(0.111$ \\
& -0.383 & Cash-low vs Cash-high & -0.299 \\
Low vs high rewards & $(0.233)$ & & $(0.219)$ \\
\hline
\end{tabular}

Note: robust standard errors in parentheses; ${ }^{* * *} p<0.01,{ }^{* *} p<0.05,{ }^{*} p<0.1$

Figure 5.2 Expected WTC under different rewards (predictive margins with 95\% CIs)

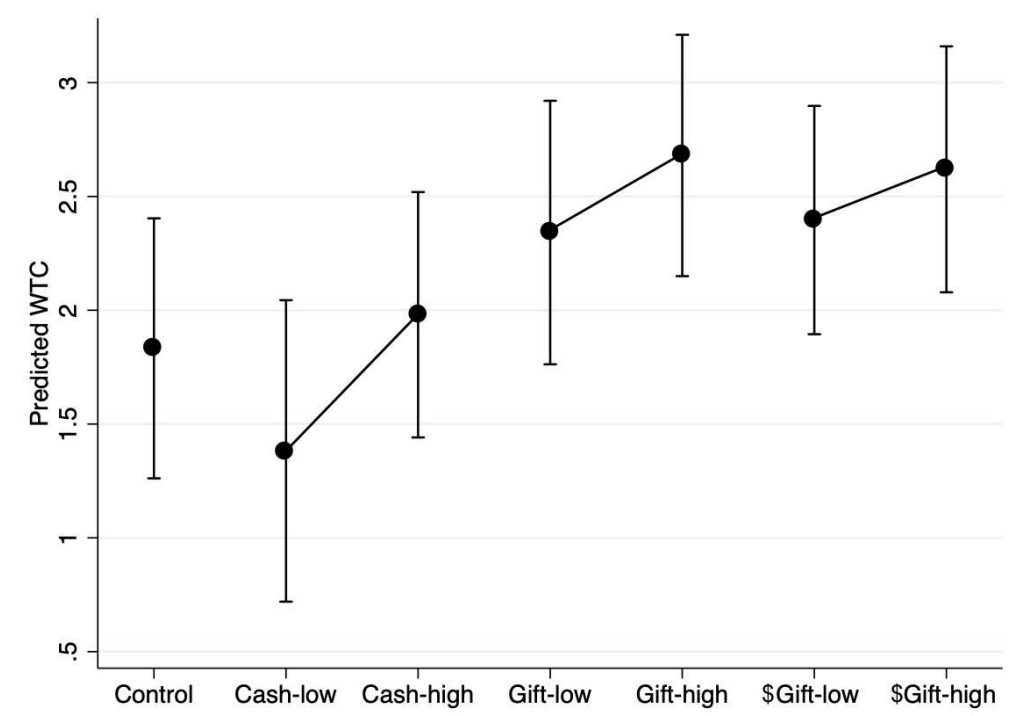

Overall, the regression results contradicted predictions that a direct monetary payment would lead to higher willingness to allow transplantation (Blair \& Kaserman 1991; Arnold et al. 2002, 1365; Becker \& Elías 2007). On the contrary, the findings found that a full funeral service would increase consent from the current system, especially when uncoupled with monetary worth. 


\subsection{Supplementary results}

Among other vignette-level variables, prior knowledge of the relative's wish to donate seemed to have the strongest link with the willingness to provide consent. In Table 5.2-1, subjects seeing vignettes with existing refusal to donate (wish to donate equaled 'No') would be significantly less willing to consent by a whopping $47.1 \%$ than those seeing the 'Yes' vignettes. Compared to confirmed wishes to donate, unclear wishes also led to a $10 \%$ decline in WTC. Indeed, these results agreed with documented cases in post-mortem donation (Siminoff et al. 2001, 74; Rodrigue et al. 2006; Ghorbani et al. 2011; Mojtabaee et al. 2018). In Tables 5.1-1 and 5.1-2, when the patient had explicitly mentioned the refusal to become a donor after death, the coefficients were significantly negative for all seven categories. The strongest impact was found in whether the reward honored the donor: compared to subjects with 'Yes' vignettes, those with 'No' vignettes judged rewards altogether $26.7 \%$ lower in this principle. On the other hand, there did not seem to be any statistical significance in all normative judgments between subjects with 'Unclear' vignettes and those with 'Yes' vignettes. Other vignette-level variables, including donor's age and gender, and death type also did not have any significant impact on both moral judgments and WTC.

Tables A.5.1-1, A.5.1-2 and A.5.2-1 in the Appendix illustrate the regression results for sociodemographic control variables: age, gender, race, religion, income, education attainment, employment and organ donor status. Because of the high number, categories without statistical significance or with very few observations (fewer than 5) were omitted from the table. Among the sociodemographic factors, the history of considering organ donation appeared to have the most significant and consistent impact on both moral judgments and WTC. Compared to subjects who had never considered becoming donors, registered organ 
donors judged rewards more positively in four ethical standards with strong significance (Pvalue $<0.05)$ and two others with weak significance $(\mathrm{P}$-value $<0.1)$. In particular, registered donors judged incentives $15.1 \%$ higher in maintaining organ donation as gifts and $12.9 \%$ higher in shunning organ commercialization. In the test for the willingness to consent, registered donors indicated their WTC 23.8\% higher, while those who were not registered donors but had considered becoming donors were $12.5 \%$ more willing than those who had never considered becoming donors (both with P-values $<0.01$ ).

Other sociodemographic factors showed significant association with moral judgments only in scattered categories. Higher income reduced normative evaluation of rewards in four principles, though the size of the effects was negligible (close to zero). Male respondents judged incentives 5.2\% lower than female respondents in conveying gratitude, though no significant associations were found for other principles. In preserving voluntariness, subjects who were employed for wages rated incentives $11.2 \%$ higher than unemployed subjects, while less educated participants judged rewards $2.7 \%$ higher than those in the next level of education attainment. Compared to white respondents, black respondents perceived rewards altogether $16.8 \%$ higher in maintaining organ donation as gifts to recipients, $9.4 \%$ higher in expressing gratitude, and $12.5 \%$ higher in honoring the donor. Lastly, compared to agnostics, Hindus judged rewards to be $25 \%$ higher in honoring the donor and keeping the gift concept in organ donation, while followers of other religions perceived rewards closer to resembling organ sale by $16.1 \%$. In the test for WTC, followers of other Christian affiliations indicated their WTC $11.3 \%$ higher than agnostics. No significance was found in the WTC of Muslim subjects, which did not confirm findings of high refusal rates among Muslims in other countries (Ghorbani et al. 2011; Mojtabaee et al. 2018; Mithra et al. 2013). 


\section{Conclusion and Discussion}

Employing a full factorial survey design, this study examined the effect of incentives in postmortem organ donation on subjects' moral judgments and willingness to provide family consent. Following the results of Heyman and Ariel on market framing in prosocial acts (2004), I utilized three methods of incentivizing: gift rewards (a funeral casket or a full funeral service), monetized gift rewards (a 2,500-dollar funeral casket or a 7,500-dollar full funeral service) and direct payments (2,500 dollars or 7,500 dollars in cash). Workers of Amazon's Mechanical Turk based in the United States constituted the entire subject pool.

On average, funeral benefits, whether presented with monetary values or not, outperformed direct payments in all seven ethical standards: (1) maintaining the concept of donated organs as gifts, (2) conveying gratitude for the donation, (3) honoring the deceased, (4) preserving voluntariness, (5) keeping away organ commercialization, (6) preserving current altruistic principles and (7) maintaining the positive view of organ donation in society. Most notably, in the analysis of rewards' impact on consent giving, a full funeral service without a revealed value was found to significantly increase family consent for post-mortem donation by $8.5 \%$ from the current incentive-free system $(\mathrm{P}$-value $<0.05)$. When the monetary worth was mentioned, the reward still increased consent giving by $7.8 \%$ with weak significance (P-value $<0.1$ ). An $8.5 \%$ increase in post-mortem donation could translate into an addition of more than 1,000 donors a year, or more than 20,000 donors since 1988 (Organ Procurement and Transplantation Network 2021).

Sociodemographic analyses found that registered donors judged rewards more favorably and were much more willing to provide consent than subjects who had never considered becoming 
donors. Among vignette factors, the prior knowledge of the relative's wish to donate was identified as the most decisive element in participants' WTC and ethical evaluations of incentives. WTC was lower in subjects assigned to vignettes where the donation wish was unclear, and where the deceased had explicitly refused to donate after death. In the latter case, subjects also judged the offered incentives problematic in all moral criteria. One could argue that financial compensation should only target families who overrule the donor's wishes or the presumed consent. However, if incentives were implemented, it would be necessary to offer them to everyone, as in the case of South Korea (Lee \& Kim 2009, 3554); selecting only families that overturned consent would encourage people to misrepresent their preferences for financial gains.

For treatments, I chose a funeral casket and a full funeral service to represent gift rewards. This design stemmed from the suggestion to employ funeral aids as an ethically appropriate incentive, and the findings that gift labeling would preserve social-market framing in altruistic acts (Arnold et al 2002, Bryce et al. 2005; Coppen et al. 2010; 167-168; Levy 2018, 414-417; Heyman \& Ariely 2004, 792). However, it could be the case that the funeral gifts in this study provoked negative sentiments, and thus could lead to refusal of financial gains (Pillutla \& Murnighan 1996; Harlé \& Sanfey 2007). Moreover, as a funeral would be a ceremonial event for the deceased, the participants could view the gift rewards as benefiting the donors rather than themselves, despite the vignette remark that the subjects would hypothetically be responsible for the expenses.

Choosing the United States as the focus country, I also acknowledged certain drawbacks with the results' interpretability for other countries. When a slight notion of money was present, U.S. subjects were shown to indicate a preference for a free-market system over the altruistic 
system for organ donation, while the same effect was not observed for non-American subjects (Caruso et al. 2013, 304). The subjects in this study, however, did not appear to favor cash prizes over the current system, while seemingly endorsing a non-monetized funeral service. From Caruso et al. 2013's results, one might expect subjects in other countries to have even more negative reactions to rewards than U.S. subjects, as exemplified by MayrhoferReinhartshuber et al.'s 2006 findings of Austrian respondents.

There are also potential directions to improve the fitness of the study. I selected two reward levels of 2,500 dollars and 7,500 dollars, because they implied two distinct compensation levels and were equivalent to the monetary value of gifts associated with funeral benefits in the design. However, one could certainly experiment with other reward magnitudes, or other types of funeral aids, such as flowers or human tasks, or non-monetary rewards, including donor medals or ceremonial events (National Health Service 2019; Ahn \& Park 2016, 123). In addition, the factorial survey was designed to reflect a realistic flow of events, including the doctor's notion of the benefits the donation could bring to recipients. However, it could be the case that this notion shifted the subjects' perception on the donation: subjects might consequently have put more value to the organs, or become more altruistically motivated to give consent. Hence, researchers could potentially explore the role of framing in this topic.

Overall, this study contributes to the literature on organ donation and behavioral economics by various means. The results highlighted the potential efficacy of a funeral service offered to the deceased donor in increasing organ supply. One most notable difference between the bestreceived scheme presented in this study and what has been suggested in the literature is in the method of incentivizing. In the experiment, the authority would hypothetically provide a complete funeral service without revealing its value, while previously, funeral benefits were 
all framed as reimbursements or contribution to the funeral cost, hence carrying a strong notion of money (Arnold et al 2002, Bryce et al. 2005; Lee \& Kim 2009; Coppen et al. 2010; Levy 2018). Utilizing factorial designs, this study further avoided potential biases in real situations, in which other highly correlated factors could not be filtered out (Auspurg \& Hinz 2014, 12-13). However, if implemented, the presented incentives, including the full funeral service, might boost consent more significantly than the results in this experiment, as Lacetera, Macis and Slonim (2013) noted that people were more willing to accept rewards in reality than in hypothetical scenarios. 


\section{REFERENCES}

Abouna, G.M. 2008. "Organ Shortage Crisis: Problems and Possible Solutions." Transplantation Proceedings 40 (1): 34-38. doi:10.1016/j.transproceed.2007.11.067. Ahn, Jisoo, and Hyun Soon Park. 2016. "Reward for Organ Donation: Is It Effective or Not as a Promotion Strategy?: Reward for Organ Donation." International Journal of Nonprofit and Voluntary Sector Marketing 21 (2): 118-29. doi:10.1002/nvsm.1550.

Altinanahtar, Alper, John R. Crooker, and Jamie B. Kruse. 2008. "Valuing Human Organs: An Application of Contingent Valuation." International Journal of Social Economics 35 (1/2): 5-14. doi:10.1108/03068290810843800.

Anker, Ashley, and Thomas Feeley. 2010. "Why Families Decline Donation: The Perspective of Organ Procurement Coordinators." Progress in Transplantation 20 (3): 239-46. doi:10.7182/prtr.20.3.y67652p636561160.

Ariely, Dan, Anat Bracha, and Stephan Meier. 2009. "Doing Good or Doing Well? Image Motivation and Monetary Incentives in Behaving Prosocially." American Economic Review 99 (1): 544-55. doi:10.1257/aer.99.1.544.

Arnold, Robert, Steven Bartlett, James Bernat, John Colonna, Donald Dafoe, Nancy

Dubler, Scott Gruber, et al. 2002. "Financial Incentives for Cadaver Organ Donation: An Ethical Reappraisal:" Transplantation 73 (8): 1361-67. doi:10.1097/00007890-200204270-00034.

Auspurg, Katrin, and Thomas Hinz. 2015. Factorial Survey Experiments. 2455 Teller Road, Thousand Oaks California 91320 United States: SAGE Publications, Inc. doi:10.4135/9781483398075.

Barber, Kerri, Sue Falvey, Claire Hamilton, Dave Collett, and Chris Rudge. 2006. "Potential for Organ Donation in the United Kingdom: Audit of Intensive Care Records.” BMJ 332 (7550): 1124-27. doi:10.1136/bmj.38804.658183.55.

Barnieh, Lianne, Scott Klarenbach, John S. Gill, Tim Caulfield, and Braden Manns. 2012. "Attitudes Toward Strategies to Increase Organ Donation: Views of the General Public and Health Professionals." Clinical Journal of the American Society of Nephrology 7 (12): 1956-63. doi:10.2215/CJN.04100412.

BBC Reality Check Team. 2017. "Organ Donation: Does an Opt-out System Increase Transplants?" BBC News, September 10, sec. Health. https://www.bbc.com/news/health-41199918. 
Becker, Gary S, and Julio Jorge Elías. 2007. "Introducing Incentives in the Market for Live and Cadaveric Organ Donations." Journal of Economic Perspectives 21 (3): 324. doi:10.1257/jep.21.3.3.

Bénabou, Roland, and Jean Tirole. 2006. "Incentives and Prosocial Behavior." American Economic Review 96 (5): 1652-78. doi:10.1257/aer.96.5.1652.

Bengali, Shashank, and Ramin Mostaghim. 2017. “'Kidney for Sale’: Iran Has a Legal Market for the Organs, but the System Doesn't Always Work." Los Angeles Times. October 15. https://www.latimes.com/world/middleeast/la-fg-iran-kidney-20171015story.html.

Blair, Roger D., and David L. Kaserman. 1991. "The Economics and Ethics of Alternative Cadaveric Organ Procurement Policies.” Yale Journal on Regulation 8: 403.

Bowles, S. 2008. "Policies Designed for Self-Interested Citizens May Undermine 'The Moral Sentiments': Evidence from Economic Experiments.” Science 320 (5883): 1605-9. doi:10.1126/science.1152110.

Brief, Arthur P., and Stephan J. Motowidlo. 1986. "Prosocial Organizational Behaviors." The Academy of Management Review 11 (4): 710. doi:10.2307/258391.

Brown, Carlos V. R., Kelli H. Foulkrod, Sarah Dworaczyk, Kit Thompson, Eric Elliot, Hassie Cooper, and Ben Coopwood. 2010. "Barriers to Obtaining Family Consent for Potential Organ Donors." Journal of Trauma: Injury, Infection \& Critical Care 68 (2): 447-51. doi:10.1097/TA.0b013e3181caab8f.

Bryce, C. L., L. A. Siminoff, P. A. Ubel, H. Nathan, A. Caplan, and R. M. Arnold. 2005. "Do Incentives Matter? Providing Benefits to Families of Organ Donors: Organ Donor Benefits." American Journal of Transplantation 5 (12): 2999-3008. doi:10.1111/j.1600-6143.2005.01106.x.

Burnham, Martin J., Yen K. Le, and Ralph L. Piedmont. 2018. "Who Is Mturk? Personal Characteristics and Sample Consistency of These Online Workers." Mental Health, Religion \& Culture 21 (9-10): 934-44. doi:10.1080/13674676.2018.1486394.

Caplan, Arthur L. 2016. "Finding a Solution to the Organ Shortage." Canadian Medical Association Journal 188 (16): 1182-83. doi:10.1503/cmaj.151260.

Capra, C. Mónica. 2004. "Mood-Driven Behavior in Strategic Interactions." American Economic Review 94 (2): 367-72. doi:10.1257/0002828041301885.

Caruso, Eugene M., Kathleen D. Vohs, Brittani Baxter, and Adam Waytz. 2013. "Mere Exposure to Money Increases Endorsement of Free-Market Systems and Social 
Inequality." Journal of Experimental Psychology: General 142 (2): 301-6. doi:10.1037/a0029288.

Chmielewski, Danielle, Liliana L. Bove, Jing Lei, Ben Neville, and Anish Nagpal. 2012. "A New Perspective on the Incentive-Blood Donation Relationship: Partnership, Congruency, and Affirmation of Competence.” Transfusion 52 (9): 1889-1900. doi:10.1111/j.1537-2995.2011.03545.x.

Clifford, Scott, Ryan M Jewell, and Philip D Waggoner. 2015. “Are Samples Drawn from Mechanical Turk Valid for Research on Political Ideology?” Research \& Politics 2 (4): 205316801562207. doi:10.1177/2053168015622072.

Coppen, Remco, Roland D. Friele, Jouke van der Zee, and Sjef K. Gevers. 2010. "The Potential of Legislation on Organ Donation to Increase the Supply of Donor Organs." Health Policy 98 (2-3): 164-70. doi:10.1016/j.healthpol.2010.05.019. Costa-Font, Joan, Mireia Jofre-Bonet, and Steven T. Yen. 2013. "Not All Incentives Wash Out the Warm Glow: The Case of Blood Donation Revisited." Kyklos 66 (4): 529-51. doi:10.1111/kykl.12034.

Delmonico, Francis L., Robert Arnold, Nancy Scheper-Hughes, Laura A. Siminoff, Jeffrey Kahn, and Stuart J. Youngner. 2002. "Ethical Incentives — Not Payment For Organ Donation." New England Journal of Medicine346 (25): 2002-5. doi:10.1056/NEJMsb013216.

Difallah, Djellel, Elena Filatova, and Panos Ipeirotis. 2018. "Demographics and Dynamics of Mechanical Turk Workers." In Proceedings of the Eleventh ACM International Conference on Web Search and Data Mining, 135-43. Marina Del Rey CA USA: ACM. doi:10.1145/3159652.3159661.

Elías, Julio J., Nicola Lacetera, and Mario Macis. 2019. "Paying for Kidneys? A Randomized Survey and Choice Experiment." American Economic Review 109 (8): 2855-88. doi:10.1257/aer.20180568.

European Commission. 2003. "Human Organ Transplantation In Europe: An Overview." ec.europa.eu. https://ec.europa.eu/health/archive/ph_threats/human_substance/documents/organ_s urvey.pdf

Frank Adams III, A., A. H. Barnett, and David L. Kaserman. 1999. "Markets for Organs: The Question of Supply." Contemporary Economic Policy 17 (2): 147-55. doi:10.1111/j.1465-7287.1999.tb00670.x.

Franz, Holly, William DeJong, Susan Wolfe, Howard Bs, Denise Rn, William Reitsma, and Carol Beasley. 1997. "Explaining Brain Death: A Critical Feature of the 
Donation Process." Journal of Transplant Coordination 7 (1): 14-21. doi:10.7182/prtr.1.7.1.287241p35jq7885n.

Ghods, Ahad J., and Shekoufeh Savaj. 2006. "Iranian Model of Paid and Regulated Living-Unrelated Kidney Donation." Clinical Journal of the American Society of Nephrology 1 (6): 1136-45. doi:10.2215/CJN.00700206.

Ghorbani, F., H.R. Khoddami-Vishteh, O. Ghobadi, S. Shafaghi, A. Rostami Louyeh, and K. Najafizadeh. 2011. "Causes of Family Refusal for Organ Donation." Transplantation Proceedings 43 (2): 405-6. doi:10.1016/j.transproceed.2011.01.031.

Girlanda, Raffaele. 2016. "Deceased Organ Donation for Transplantation: Challenges and Opportunities." World Journal of Transplantation 6 (3): 451. doi:10.5500/wjt.v6.i3.451.

Glynn, Simone A., Alan E. Williams, Catharie C. Nass, James Bethel, Debra Kessler, Edward P. Scott, Joy Fridey, Steven H. Kleinman, George B. Schreiber, and Retrovirus Epidemiology Donor Study. 2003. "Attitudes toward Blood Donation Incentives in the United States: Implications for Donor Recruitment." Transfusion 43 (1): 7-16. doi:10.1046/j.1537-2995.2003.00252.x. Gneezy, Uri, and Aldo Rustichini. 2000. "Pay Enough or Don’t Pay at All*." Quarterly Journal of Economics 115 (3): 791-810. doi:10.1162/003355300554917.

Goette, Lorenz F., and Alois Stutzer. 2008. "Blood Donations and Incentives: Evidence from a Field Experiment.” SSRN Electronic Journal. doi:10.2139/ssrn.1153406.

Harlé, Katia M., and Alan G. Sanfey. 2007. "Incidental Sadness Biases Social Economic Decisions in the Ultimatum Game.” Emotion 7 (4): 876-81. doi:10.1037/15283542.7.4.876.

Hauser, David J., and Norbert Schwarz. 2016. "Attentive Turkers: MTurk Participants Perform Better on Online Attention Checks than Do Subject Pool Participants." Behavior Research Methods 48 (1): 400-407. doi:10.3758/s13428-015-0578-z. Heyman, J., and D. Ariely. 2004. "Effort for Payment: A Tale of Two Markets." Psychological Science 15 (11): 787-93. doi:10.1111/j.0956-7976.2004.00757.x. Hippen, Benjamin. 2008. "Organ Sales and Moral Travails: Lessons from the Living Kidney Vendor Program in Iran." Cato Policy Analysis Series 614.

Human Tissue Authority. 2017. "Under What Circumstances Can My Organs Be Donated after My Death?” hta.gov.uk. https://www.hta.gov.uk/faq/under-whatcircumstances-can-my-organs-be-donated-after-my-death. 
IRODaT - International Registry in Organ Donation and Transplantation. 2018. "Final Numbers 2017.” IRODaT.

http://www.irodat.org/img/database/pdf/IRODaT\%20Newsletter\%202017.pdf.

Jasper, J D., Carol A. E. Nickerson, Peter A. Ubel, and David A. Asch. 2004. "Altruism, Incentives, and Organ Donation: Attitudes of the Transplant Community." Medical Care 42 (4): 378-86. doi:10.1097/01.mlr.0000118863.47574.0f.

Jeong, Chang Rok. 2018. "Is a System of Compensation for the Donation of Human Organs Ethically Justified? Focused on South Korea." Journal of Infectious Diseases and Medical Microbiology 2 (2): 17-22.

Kessler, Judd B., and Alvin E. Roth. 2014. 'Don't Take 'no' for an Answer: An Experiment with Actual Organ Donor Registrations." National Bureau of Economic Research, No. w20378, .

Kinnaman, Thomas C. 2006. "Policy Watch: Examining the Justification for Residential Recycling." Journal of Economic Perspectives 20 (4): 219-32. doi:10.1257/jep.20.4.219.

Kube, Sebastian, Michel André Maréchal, and Clemens Puppe. 2012. "The Currency of Reciprocity: Gift Exchange in the Workplace.” American Economic Review 102 (4): 1644-62. doi:10.1257/aer.102.4.1644.

Lacetera, Nicola, and Mario Macis. 2010. "Do All Material Incentives for Pro-Social Activities Backfire? The Response to Cash and Non-Cash Incentives for Blood Donations." Journal of Economic Psychology 31 (4): 738-48. doi:10.1016/j.joep.2010.05.007.

Lacetera, Nicola, and Mario Macis. 2013. "Time for Blood: The Effect of Paid Leave Legislation on Altruistic Behavior." Journal of Law, Economics, and Organization 29 (6): 1384-1420. doi:10.1093/jleo/ews019.

Lacetera, Nicola, Mario Macis, and Robert Slonim. 2013. "Economic Rewards to Motivate Blood Donations." Science 340 (6135): 927-28. doi:10.1126/science.1232280.

Lacetera, Nicola, Mario Macis, and Robert Slonim. 2014. "Rewarding Volunteers: A Field Experiment." Management Science 60 (5): 1107-29. doi:10.1287/mnsc.2013.1826.

Lee, S.D., and J.H. Kim. 2009. "Changes in the Organ Procurement System in South Korea: Effects on Brain-Dead Donor Numbers.” Transplantation Proceedings 41 (9): 3551-55. doi:10.1016/j.transproceed.2009.06.210. 
Leonard, Thomas C. 2004. "The Price Is Wrong: Causes and Consequences of Ethical Restraint of Trade." Journal Des Economistes et Des Etudes Humaines 14 (2). doi:10.2202/1145-6396.1130.

Lerner, Jennifer S., Deborah A. Small, and George Loewenstein. 2004. "Heart Strings and Purse Strings. Carryover Effects of Emotions on Economic Decisions." Psychological Science 15 (5): 337-41. doi:10.1111/j.0956-7976.2004.00679.x.

Levy, Melanie. 2018. "State Incentives to Promote Organ Donation: Honoring the Principles of Reciprocity and Solidarity Inherent in the Gift Relationship." Journal of Law and the Biosciences 5 (2): 398-435.

Mayrhofer-Reinhartshuber, D., A. Fitzgerald, G. Benetka, and R. Fitzgerald. 2006. "Effects of Financial Incentives on the Intention to Consent to Organ Donation: A Questionnaire Survey." Transplantation Proceedings 38 (9): 2756-60. doi:10.1016/j.transproceed.2006.08.134.

McCarrick, Pat Milmoe, and Martina Darragh. 2003. "Incentives for Providing Organs." Kennedy Institute of Ethics Journal 13 (1): 53-64. doi:10.1353/ken.2003.0006.

McCredie, Morgan N., and Leslie C. Morey. 2019. "Who Are the Turkers? A Characterization of MTurk Workers Using the Personality Assessment Inventory." Assessment 26 (5): 759-66. doi:10.1177/1073191118760709.

Meier, Stephan. 2007. "Do Subsidies Increase Charitable Giving in the Long Run? Matching Donations in a Field Experiment." Journal of the European Economic Association 5 (6): 1203-22. doi:10.1162/JEEA.2007.5.6.1203.

Mellström, Carl, and Magnus Johannesson. 2008. "Crowding Out in Blood Donation: Was Titmuss Right?” Journal of the European Economic Association 6 (4): 845-63. doi:10.1162/JEEA.2008.6.4.845.

Min, Sang Il, Seong Yup Kim, Yang Jin Park, Seung-Kee Min, Yon Su Kim, Curie Ahn, Sang Joon Kim, and Jongwon Ha. 2010. "Trends in Deceased Organ Donation and Utilization in Korea: 2000-2009." Journal of Korean Medical Science 25 (8): 112227.

Mithra, Prasanna, Prithvishree Ravindra, B Unnikrishnan, T Rekha, Tanuj Kanchan, Nithin Kumar, Mohan Papanna, Vaman Kulkarni, Ramesh Holla, and K Divyavaraprasad. 2013. "Perceptions and Attitudes towards Organ Donation among People Seeking Healthcare in Tertiary Care Centers of Coastal South India." Indian Journal of Palliative Care 19 (2): 83. doi:10.4103/0973-1075.116701.

Mojtabaee, Meysam, Fariba Ghorbani, Mojtaba Mohsenzadeh, and Farahnaz Sadegh Beigee. 2017. "Update on Causes of Family Refusal for Organ Donation and the 
Related Factors: Reporting the Changes Over 6 Years.” Transplantation 101 (August): S44-45. doi:10.1097/01.tp.0000525044.96772.d9.

National Academies of Sciences, Engineering, and Medicine. 2018. Opportunities for Organ Donor Intervention Research: Saving Lives by Improving the Quality and Quantity of Organs for Transplantation. National Academies Press.

National Funeral Directors Association. 2019. "Statistics.” nfda.org. https://nfda.org/news/statistics.

National Health Service. 2019. “Order of St John UK Award.” NHS Organ Donation. http://www.organdonation.nhs.uk/helping-you-to-decide/real-life-stories/order-of-stjohn-uk-award/.

Organ Procurement and Transplantation Network. 2021. "National Data - OPTN." https://optn.transplant.hrsa.gov/data/view-data-reports/national-data/\#\%3E.

Peters, Thomas G. 2002. "A Stand in Favor of Financial Incentives in Organ Recovery." Dialysis \& Transplantation 31 (5): 322-25.

Petersen, Thomas Søbirk, and Kasper Lippert-Rasmussen. 2012. "Ethics, Organ Donation and Tax: A Proposal." Journal of Medical Ethics 38 (8): 451-57. doi:10.1136/medethics-2011-100163.

Pew Research Center. 2019. "Detailed Tables: Trends in Religious Composition of U.S. Adults.” Pewforum.org. https://www.pewforum.org/wpcontent/uploads/sites/7/2019/11/Detailed-tables-for-upload-11.11.19.pdf.

Pham, V. 2019. “Incentivizing of Family Consent for Organ Donation”. Master's thesis, University of Cologne.

Pillutla, Madan M., and J.Keith Murnighan. 1996. "Unfairness, Anger, and Spite: Emotional Rejections of Ultimatum Offers." Organizational Behavior and Human Decision Processes 68 (3): 208-24. doi:10.1006/obhd.1996.0100.

Prendergast, Canice, and Lars Stole. 2001. "The Non-Monetary Nature of Gifts." European Economic Review 45 (10): 1793-1810. doi:10.1016/S00142921(00)00102-1.

Radcliffe-Richards, J, As Daar, Rd Guttmann, R Hoffenberg, I Kennedy, M Lock, Ra Sells, and N Tilney. 1998. "The Case for Allowing Kidney Sales.” The Lancet 351 (9120): 1950-52. doi:10.1016/S0140-6736(97)08211-1.

Ralph, A., J. R. Chapman, J. Gillis, J. C. Craig, P. Butow, K. Howard, M. Irving, B. Sutanto, and A. Tong. 2014. "Family Perspectives on Deceased Organ Donation: Thematic Synthesis of Qualitative Studies: Family Views on Deceased Donation." American Journal of Transplantation 14 (4): 923-35. doi:10.1111/ajt.12660. 
Rodrigue, J. R., D. L. Cornell, and R. J. Howard. 2006. "Organ Donation Decision: Comparison of Donor and Nondonor Families." American Journal of Transplantation 6 (1): 190-98. doi:10.1111/j.1600-6143.2005.01130.x.

Rodríguez-Arias, David, Linda Wright, and David Paredes. 2010. "Success Factors and Ethical Challenges of the Spanish Model of Organ Donation." The Lancet 376 (9746): 1109-12. doi:10.1016/S0140-6736(10)61342-6.

Roszkowski, Michael J., and Margot Soven. 2010. "Shifting Gears: Consequences of Including Two Negatively Worded Items in the Middle of a Positively Worded Questionnaire." Assessment \& Evaluation in Higher Education 35 (1): 113-30. doi:10.1080/02602930802618344.

Rothman, S. M., and D. J. Rothman. 2006. "The Hidden Cost of Organ Sale.: The Authors Argue That Establishing a Market in Organs May Have an Unintended Adverse Consequences on Organ Donation and a Detrimental Effect on the Medical Profession. See Also Editorial by Robert Gaston in This Issue on Page 1503.” American Journal of Transplantation 6 (7): 1524-28. doi:10.1111/j.16006143.2006.01325.x.

Sanchez, Ana M., Dannie I. Ameti, George B. Schreiber, Ruth A. Thomson, Annie Lo, James Bethel, Alan E. Williams, and for the Retrovirus Epidemiology Donor Study. 2001. "The Potential Impact of Incentives on Future Blood Donation Behavior." Transfusion 41 (2): 172-78. doi:10.1046/j.1537-2995.2001.41020172.x.

Sandel, Michael J. 2012. What Money Can't Buy: The Moral Limits of Markets. 1st ed. New York: Farrar, Straus and Giroux.

Shaw, David, Denie Georgieva, Bernadette Haase, Dale Gardiner, Penney Lewis, Nichon Jansen, Tineke Wind, Undine Samuel, Maryon McDonald, and Rutger Ploeg. 2017. "Family Over Rules? An Ethical Analysis of Allowing Families to Overrule Donation Intentions." Transplantation 101 (3): 482-87. doi:10.1097/TP.0000000000001536.

Siminoff, Laura A. 2001. "Factors Influencing Families' Consent for Donation of Solid Organs for Transplantation.” JAMA 286 (1): 71. doi:10.1001/jama.286.1.71.

Smith, Martin, B. Dominguez-Gil, D. M. Greer, A. R. Manara, and M. J. Souter. 2019. "Organ Donation after Circulatory Death: Current Status and Future Potential." Intensive Care Medicine 45 (3): 310-21. doi:10.1007/s00134-019-05533-0.

Snowbeck, C. 2002. “Organ Donor Funeral Aid Scrapped.” Pittsburgh Post-Gazette. http://old.post-gazette.com/healthscience/20020201donors0201p2.asp. 
Soyama, Akihiko, and Susumu Eguchi. 2016. "The Current Status and Future Perspectives of Organ Donation in Japan: Learning from the Systems in Other Countries." Surgery Today 46 (4): 387-92. doi:10.1007/s00595-015-1211-6. Sque, M., T. Long, and S. Payne. 2005. “Organ Donation: Key Factors Influencing Families' Decision-Making." Transplantation Proceedings 37 (2): 543-46. doi:10.1016/j.transproceed.2004.11.038.

Sque, Magi, Tracy Long, Sheila Payne, and Diana Allardyce. 2008. "Why Relatives Do Not Donate Organs for Transplants: 'Sacrifice' or 'Gift of Life'?” Journal of Advanced Nursing 61 (2): 134-44. doi:10.1111/j.1365-2648.2007.04491.x.

Statista. 2021. "Organ Donors United States by Age 2020."

https://www.statista.com/statistics/398442/total-number-of-us-organ-donors-by-agegroup/.

Twenge, Jean M., Roy F. Baumeister, C. Nathan DeWall, Natalie J. Ciarocco, and J. Michael Bartels. 2007. "Social Exclusion Decreases Prosocial Behavior." Journal of Personality and Social Psychology 92 (1): 56-66. doi:10.1037/0022-3514.92.1.56.

Ubel, Peter A., Cindy L. Bryce, Laura A. Siminoff, Arthur L. Caplan, and Robert M. Arnold. 2000. "Essay: Pennsylvania's Voluntary Benefits Program: Evaluating An Innovative Proposal For Increasing Organ Donation: The Greenwall Foundation Is Funding an Evaluation of This Controversial Pilot Program." Health Affairs 19 (5): 206-11. doi:10.1377/hlthaff.19.5.206.

U.S. Census Bureau. 2019. "QuickFacts: United States." https://www.census.gov/quickfacts/fact/table/US/PST045219.

Weale, Albert, Marilyn Strathern, and Nuffield Council on Bioethics. 2011. Human Bodies: Donation for Medicine and Research. London: Nuffield Council on Bioethics.

Weinberg, Jill, Jeremy Freese, and David McElhattan. 2014. "Comparing Data Characteristics and Results of an Online Factorial Survey between a PopulationBased and a Crowdsource-Recruited Sample.” Sociological Science 1: 292-310. doi:10.15195/v1.a19.

Wig, N., P. Aggarwal, S. Kailash, R. Handa, and J. P. Wali. 1999. "Awareness of Brain Death and Organ Transplantation among High School Children." The Indian Journal of Pediatrics 66 (2): 189-92. doi:10.1007/BF02761204.

Willsher, Kim. 2017. "France Introduces Opt-out Policy on Organ Donation." The Guardian. http://www.theguardian.com/society/2017/jan/02/france-organ-donationlaw. 
Yang, Adelle Xue, Christopher K. Hsee, and Oleg Urminsky. 2014. "Eager to Help Yet Reluctant to Give: How Pro-Social Effort and Pro-Social Choices Diverge." SSRN Electronic Journal. doi:10.2139/ssrn.2733331.

Yilmaz, Tonguc Utku. 2011. "Importance of Education in Organ Donation." Experimental and Clinical Transplantation: Official Journal of the Middle East Society for Organ Transplantation 9 (6): 370-75.

Zargooshi, Javaad. 2001. "Quality of Life of Iranian Kidney 'donors." Journal of Urology 166 (5): 1790-99. doi:10.1016/S0022-5347(05)65677-7. 


\section{APPENDIX}

Table A.4.2-1 Phrasing of all ethical judgments

\begin{tabular}{|c|c|}
\hline Principle & Statement \\
\hline $\begin{array}{l}\text { (1) Maintaining the } \\
\text { concept of organ } \\
\text { donation as gifts }\end{array}$ & $\begin{array}{l}\text { A: "With this initiative, I would continue to view donated organs as } \\
\text { gifts from the donors to the recipients." } \\
\text { B: "With this initiative, I would no longer view donated organs as gifts } \\
\text { from the donors to the recipients." }\end{array}$ \\
\hline (2) Showing gratitude & $\begin{array}{l}\text { A: "This initiative would convey a lot of gratitude for the donation." } \\
\text { B: "This initiative would not convey any gratitude for the donation." }\end{array}$ \\
\hline (3) Honoring the donor & $\begin{array}{l}\text { A: "This initiative would greatly honor the deceased donor." } \\
\text { B: "This initiative would seriously dishonor the deceased donor." }\end{array}$ \\
\hline $\begin{array}{l}\text { (4) Maintaining } \\
\text { voluntariness }\end{array}$ & $\begin{array}{l}\text { A: "This initiative would keep organ donation voluntary." } \\
\text { B: "This initiative would make organ donation no longer voluntary." }\end{array}$ \\
\hline $\begin{array}{l}\text { (5) Keeping away organ } \\
\text { commercialization }\end{array}$ & $\begin{array}{l}\text { A: "This initiative would keep organ donation far from sales of human } \\
\text { organs." } \\
\text { B: "This initiative would make organ donation equivalent to sales of } \\
\text { human organs." }\end{array}$ \\
\hline
\end{tabular}

(6) Maintaining the

A: "This initiative would keep the current standards of altruism concept of organ unaffected."

donation as gifts

B: "This initiative would seriously lower the current standards of altruism."

(7) Maintaining society's positive view

A: "With this initiative, our society would continue to regard organ donation as good."

B: "With this initiative, our society would no longer regard organ donation as good." 
Figure A.4.2-1 11-point scale for ethical evaluation

5 (Strongly agree with Statement A)

$\bigcirc 4$

$\bigcirc$

$\bigcirc 2$

$\bigcirc 1$

$\bigcirc 0$ (Neutral)

$-1$

$-2$

$-3$

$-4$

-5 (Strongly agree with Statement B)

Figure A.4.2-2 11-point scale for willingness to provide family consent (WTC)

5 (Extremely likely)

$\bigcirc 4$

$\bigcirc$

$\bigcirc 2$

$\bigcirc 1$

$\bigcirc 0$ (Neither likely nor unlikely)

$-1$

$-2$

$-3$

$-4$

$\bigcirc-5$ (Extremely unlikely) 
Table A.4.2-2 Phrasing for different incentive groups

\begin{tabular}{ll}
\hline Type $\quad$ Magnitude & Phrasing \\
\hline Gift $\quad$ Low & You would pay for the funeral service of your relative. \\
& $\begin{array}{l}\text { To share its condolences with the surviving family and to express its } \\
\text { gratitude, the local authority would offer the funeral casket as an honor } \\
\text { gift to any organ donor. }\end{array}$ \\
High & You would pay for the funeral service of your relative. \\
& $\begin{array}{l}\text { To share its condolences with the surviving family and to express its } \\
\text { gratitude, the local authority would offer a full funeral service as an honor } \\
\text { gift to any organ donor. The full funeral service provided would include } \\
\text { venue, transportation, casket, and all funeral equipment and professional } \\
\text { services. }\end{array}$
\end{tabular}

\$Gift Low You would pay for the funeral service of your relative. Among various costs is $\$ \mathbf{2 , 5 0 0}$ for the funeral casket.

To share its condolences with the surviving family and to express its gratitude, the local authority would offer the funeral casket as an honor gift to any organ donor.

High You would pay for the funeral service of your relative. The average cost of a full funeral service is $\$ 7,500$.

To share its condolences with the surviving family and to express its gratitude, the local authority would offer a full funeral service as an honor gift to any organ donor. The full funeral service provided would include venue, transportation, casket, and all funeral equipment and professional services.

Cash Low To share its condolences with the surviving family and to express its gratitude, the local authority would compensate the family of any organ donor $\$ \mathbf{2 , 5 0 0}$ in cash. You would be the recipient of this payment.

High To share its condolences with the surviving family and to express its gratitude, the local authority would compensate the family of any organ donor $\$ 7,500$ in cash. You would be the recipient of this payment. 
Table A.4.3-1 Dimensions, levels and vignettes of the factorial survey design

\begin{tabular}{|c|c|c|c|}
\hline & Dimension & Level & Vignette \\
\hline \multirow[t]{3}{*}{1} & Age & 1 & 25-year-old \\
\hline & & 2 & 40-year-old \\
\hline & & 3 & 55-year-old \\
\hline 2 & Gender & 1 & Female (sister) \\
\hline & & 2 & Male (brother) \\
\hline \multirow[t]{2}{*}{3} & Death type & 1 & Brain death \\
\hline & & 2 & Circulatory death \\
\hline \multirow[t]{3}{*}{4} & Patient's wish & 1 & $\begin{array}{l}\text { Unclear (patient had never mentioned whether he or } \\
\text { she would want to be an organ donor) }\end{array}$ \\
\hline & & 2 & $\begin{array}{l}\text { Yes (patient had explicitly mentioned that he or she } \\
\text { would want to be an organ donor) }\end{array}$ \\
\hline & & 3 & $\begin{array}{l}\text { No (potential donor had explicitly mentioned that he } \\
\text { or she would not want to be an organ donor) }\end{array}$ \\
\hline \multirow[t]{7}{*}{5} & Reward & 1 & Control \\
\hline & & 2 & Funeral casket \\
\hline & & 3 & Full funeral service \\
\hline & & 4 & Funeral casket worth $\$ 2,500$ \\
\hline & & 5 & Full funeral service worth $\$ 7,500$ \\
\hline & & 6 & $\$ 2,500$ in cash \\
\hline & & 7 & $\$ 7,500$ in cash \\
\hline
\end{tabular}


Table A.4.3-2 Summary of experimental flow

\begin{tabular}{|c|c|}
\hline Stage & Core details \\
\hline Introduction & $\begin{array}{l}\text { - Briefing and participation consent } \\
\text { - Sociodemographic questionnaire }\end{array}$ \\
\hline $\begin{array}{l}\text { Hypothetical } \\
\text { dimensions }\end{array}$ & $\begin{array}{l}\text { - (Screen 1) Setup of the hypothetical environment: In a hospital } \\
\text { setting, a doctor approached the subject with news about a close } \\
\text { family member. } \\
\text { - (Screen 2) The subject was provided with vignettes of a } \\
\text { hypothetical patient: } \\
\text { ○ Age of the patient } \\
\text { - Relationship with the participant } \\
\text { - Type of death (brain death or circulatory death) } \\
\text { - Subject was then asked to consider donating the deceased's } \\
\text { organs. In addition, the prompt mentioned: } \\
\text { 'A long list of waiting transplant patients } \\
\text {-The donated organs would greatly benefit others' well-beings } \\
\text { - Subject had the right to make the donation decision } \\
\text { - (Screen 3) The deceased's existing wish to become a donor (yes, } \\
\text { no, or unclear) was mentioned. }\end{array}$ \\
\hline Incentivizing & $\begin{array}{l}\text { - The subject was randomly presented with one of the three } \\
\text { methods of incentivizing: } \\
\text { - Direct cash payment (either 2,500 or 7,500 dollars) } \\
\text { - A gift with monetary value (either a funeral casket worth 2,500 } \\
\text { or a full funeral service worth 7,500 dollars) } \\
\text {-A gift without monetary value (either a funeral casket or a full } \\
\text { funeral service) } \\
\text { - The subject was asked to evaluate the method of incentivizing by } \\
7 \text { ethical principles (section } 4.2 .2 \text { ) } \\
\text { - The subject was asked about his/her willingness to consent under } \\
\text { this incentive } \\
\text { (The control group would only see the last stage) }\end{array}$ \\
\hline Closing & End of survey message \\
\hline
\end{tabular}


Table A.4.6 Summary of respondents' characteristics in comparison to the U.S. population

\begin{tabular}{lll}
\hline Factor & Respondents & U.S. Population (2019) \\
\hline Median age & 35 & 38.4 \\
\% Female & $56.2 \%$ & $50.6 \%$ \\
Median household income & $\$ 60,000$ to $\$ 70,000$ & $\$ 62,843$ \\
Racial makeup: & & \\
White & $76.6 \%$ & $76.3 \%$ \\
Hispanic & $5.6 \%$ & $18.5 \%$ \\
Black & $5.2 \%$ & $13.4 \%$ \\
Asian & $9.4 \%$ & $5.9 \%$ \\
Religious makeup: & & \\
Christian & $53.7 \%$ & $65 \%$ \\
Jewish & $2.9 \%$ & $2 \%$ \\
Muslim & $0.9 \%$ & $1 \%$ \\
Buddhist & $1.3 \%$ & $1 \%$ \\
Hindu & $2.0 \%$ & $1 \%$ \\
Non-religious & $11.8 \%$ & $17 \%$ \\
Agnostic & $12.0 \%$ & $4 \%$ \\
Atheist & $11.8 \%$ & $5 \%$ \\
\hline
\end{tabular}

U.S. population sources: U.S. Census 2019; Pew Research Center 2019 
Table A.5.1-1 Regression results of ethical evaluations (1-4) for selected sociodemographic factors (continuation of Table 5.1-1)

\begin{tabular}{|c|c|c|c|c|}
\hline & $\begin{array}{l}\text { Maintain OD } \\
\text { as gifts }\end{array}$ & $\begin{array}{l}\text { Convey } \\
\text { gratitude }\end{array}$ & $\begin{array}{l}\text { Honor the } \\
\text { donor }\end{array}$ & $\begin{array}{l}\text { Preserve } \\
\text { voluntariness }\end{array}$ \\
\hline \multicolumn{5}{|c|}{ OD registration (vs. "No and have never considered") } \\
\hline $\begin{array}{l}\text { No but have } \\
\text { considered }\end{array}$ & $\begin{array}{l}0.698 \\
(0.539)\end{array}$ & $\begin{array}{l}0.715 \\
(0.452)\end{array}$ & $\begin{array}{l}0.295 \\
(0.483)\end{array}$ & $\begin{array}{l}0.380 \\
(0.526)\end{array}$ \\
\hline Yes & $\begin{array}{l}1.507^{* * *} \\
(0.448)\end{array}$ & $\begin{array}{l}1.205^{\star \star *} \\
(0.393)\end{array}$ & $\begin{array}{l}0.699^{\star} \\
(0.410)\end{array}$ & $\begin{array}{l}0.553 \\
(0.461)\end{array}$ \\
\hline Age & $\begin{array}{l}-0.007 \\
(0.017)\end{array}$ & $\begin{array}{l}0.010 \\
(0.012)\end{array}$ & $\begin{array}{l}0.022 \\
(0.015)\end{array}$ & $\begin{array}{l}0.021 \\
(0.017)\end{array}$ \\
\hline Income & $\begin{array}{l}-0.018 \\
(0.028)\end{array}$ & $\begin{array}{l}-0.055^{\star *} \\
(0.021)\end{array}$ & $\begin{array}{l}-0.055^{\star *} \\
(0.025)\end{array}$ & $\begin{array}{l}-0.036 \\
(0.027)\end{array}$ \\
\hline $\begin{array}{l}\text { Male respondent }{ }^{1} \\
\text { (vs. female) }\end{array}$ & $\begin{array}{l}0.133 \\
(0.264)\end{array}$ & $\begin{array}{l}-0.518^{* *} \\
(0.208)\end{array}$ & $\begin{array}{l}-0.133 \\
(0.246)\end{array}$ & $\begin{array}{l}-0.054 \\
(0.276)\end{array}$ \\
\hline $\begin{array}{l}\text { Black respondent }{ }^{2} \\
\text { (vs. white) }\end{array}$ & $\begin{array}{l}1.680^{* * *} \\
(0.538)\end{array}$ & $\begin{array}{l}0.944^{* *} \\
(0.407)\end{array}$ & $\begin{array}{l}1.250^{* *} \\
(0.507)\end{array}$ & $\begin{array}{l}0.366 \\
(0.702)\end{array}$ \\
\hline $\begin{array}{l}\text { Education } \\
\text { attainment }\end{array}$ & $\begin{array}{l}-0.081 \\
(0.114)\end{array}$ & $\begin{array}{l}0.006 \\
(0.090)\end{array}$ & $\begin{array}{l}-0.011 \\
(0.104)\end{array}$ & $\begin{array}{l}-0.269^{* *} \\
(0.116)\end{array}$ \\
\hline \multicolumn{5}{|c|}{ Employment $^{3}$ (vs. unemployed) } \\
\hline Homemaker & $\begin{array}{l}0.048 \\
(0.813)\end{array}$ & $\begin{array}{l}-0.646 \\
(0.571)\end{array}$ & $\begin{array}{l}-0.358 \\
(0.653)\end{array}$ & $\begin{array}{l}1.271^{*} \\
(0.749)\end{array}$ \\
\hline Employed for wages & $\begin{array}{l}-0.045 \\
(0.626)\end{array}$ & $\begin{array}{l}-0.461 \\
(0.453)\end{array}$ & $\begin{array}{l}-0.260 \\
(0.511)\end{array}$ & $\begin{array}{l}1.119^{* *} \\
(0.552)\end{array}$ \\
\hline Retired & $\begin{array}{l}0.074 \\
(0.923)\end{array}$ & $\begin{array}{l}-0.581 \\
(0.700)\end{array}$ & $\begin{array}{l}-0.780 \\
(0.750)\end{array}$ & $\begin{array}{l}0.579 \\
(0.830)\end{array}$ \\
\hline \multicolumn{5}{|l|}{ Religion ${ }^{4}$ (vs. agnostic) } \\
\hline Catholic & $\begin{array}{l}0.184 \\
(0.420)\end{array}$ & $\begin{array}{l}0.015 \\
(0.353)\end{array}$ & $\begin{array}{l}0.587 \\
(0.387)\end{array}$ & $\begin{array}{l}0.841^{*} \\
(0.429)\end{array}$ \\
\hline Hindu & $\begin{array}{l}2.574^{* * *} \\
(0.859)\end{array}$ & $\begin{array}{l}0.811 \\
(0.944)\end{array}$ & $\begin{array}{l}2.496^{* * *} \\
(0.923)\end{array}$ & $\begin{array}{l}1.198 \\
(1.110)\end{array}$ \\
\hline
\end{tabular}

Note: robust standard errors in parentheses; ${ }^{* * *} p<0.01,{ }^{* *} p<0.05,{ }^{*} p<0.1$

Categories (with no significant relationships, or with very small observations) not shown above included: ${ }^{1}$ other gender. ${ }^{2}$ Asian, Hispanic or Latino, mixed-race, Native American, Pacific Islander. ${ }^{3}$ homemaker, student, selfemployed, unable to work. ${ }^{4}$ Atheist, Buddhist, Jewish, Jehovah's Witness, Mormon, Muslim, not religious, Orthodox Christian, other Christian affiliations, other religion, Protestant 
Table A.5.1-2 Regression results of ethical evaluations (5-7) for selected sociodemographic factors (continuation of Table 5.1-2)

\begin{tabular}{|c|c|c|c|}
\hline & $\begin{array}{l}\text { Not equivalent to } \\
\text { organ sale }\end{array}$ & $\begin{array}{l}\text { Preserve altruistic } \\
\text { standards }\end{array}$ & $\begin{array}{l}\text { Maintain positive view } \\
\text { of society }\end{array}$ \\
\hline \multicolumn{4}{|c|}{ OD registration (vs. "No and have never considered") } \\
\hline No but have considered & $\begin{array}{l}0.367 \\
(0.517)\end{array}$ & $\begin{array}{l}0.244 \\
(0.484)\end{array}$ & $\begin{array}{l}0.746^{*} \\
(0.441)\end{array}$ \\
\hline Yes & $\begin{array}{l}1.286^{\star * \star} \\
(0.448)\end{array}$ & $\begin{array}{l}0.836^{*} \\
(0.426)\end{array}$ & $\begin{array}{l}1.030^{* * *} \\
(0.380)\end{array}$ \\
\hline Age & $\begin{array}{l}0.019 \\
(0.016)\end{array}$ & $\begin{array}{l}0.028 \\
(0.017)\end{array}$ & $\begin{array}{l}0.038^{* * *} \\
(0.014)\end{array}$ \\
\hline Income & $\begin{array}{l}-0.057^{* *} \\
(0.026)\end{array}$ & $\begin{array}{l}-0.049^{\star *} \\
(0.025)\end{array}$ & $\begin{array}{l}-0.028 \\
(0.021)\end{array}$ \\
\hline $\begin{array}{l}\text { Male respondent }{ }^{1} \\
\text { (vs. female) }\end{array}$ & $\begin{array}{l}0.206 \\
(0.260)\end{array}$ & $\begin{array}{l}0.269 \\
(0.250)\end{array}$ & $\begin{array}{l}0.0189 \\
(0.215)\end{array}$ \\
\hline $\begin{array}{l}\text { Black respondent }{ }^{2} \\
\text { (vs. white) }\end{array}$ & $\begin{array}{l}0.778 \\
(0.694)\end{array}$ & $\begin{array}{l}0.472 \\
(0.662)\end{array}$ & $\begin{array}{l}0.840 \\
(0.533)\end{array}$ \\
\hline Education attainment & $\begin{array}{l}-0.140 \\
(0.110)\end{array}$ & $\begin{array}{l}-0.099 \\
(0.101)\end{array}$ & $\begin{array}{l}-0.094 \\
(0.093)\end{array}$ \\
\hline \multicolumn{4}{|c|}{ Employment $^{3}$ (vs. unemployed) } \\
\hline Employed for wages & $\begin{array}{l}-0.050 \\
(0.542)\end{array}$ & $\begin{array}{l}0.648 \\
(0.565)\end{array}$ & $\begin{array}{l}-0.126 \\
(0.468)\end{array}$ \\
\hline Retired & $\begin{array}{l}-0.465 \\
(0.831)\end{array}$ & $\begin{array}{l}-0.002 \\
(0.840)\end{array}$ & $\begin{array}{l}-1.294^{*} \\
(0.748)\end{array}$ \\
\hline \multicolumn{4}{|l|}{ Religion ${ }^{4}$ (vs. agnostic) } \\
\hline Catholic & $\begin{array}{l}0.869^{* *} \\
(0.402)\end{array}$ & $\begin{array}{l}0.707^{*} \\
(0.397)\end{array}$ & $\begin{array}{l}0.045 \\
(0.348)\end{array}$ \\
\hline Other religion & $\begin{array}{l}-1.605^{\star *} \\
(0.739)\end{array}$ & $\begin{array}{l}-0.704 \\
(0.705)\end{array}$ & $\begin{array}{l}-1.059 \\
(0.672)\end{array}$ \\
\hline
\end{tabular}

Note: robust standard errors in parentheses; ${ }^{* * *} p<0.01,{ }^{* *} p<0.05,{ }^{*} p<0.1$

Categories (with no significant relationships, or with very small observations) not shown above included: ${ }^{1}$ other gender. ${ }^{2}$ Asian, Hispanic or Latino, mixed-race, Native American, Pacific Islander. ${ }^{3}$ homemaker, student, selfemployed, unable to work. ${ }^{4}$ Atheist, Buddhist, Hindu, Jewish, Jehovah's Witness, Mormon, Muslim, not religious, Orthodox Christian, other Christian affiliations, Protestant 
Table A.5.2-1 Regression results of willingness to consent (WTC) for selected sociodemographic factors (continuation of Table 5.2-1)

\begin{tabular}{|c|c|c|c|}
\hline & WTC & & WTC \\
\hline $\begin{array}{l}\text { Male respondent }{ }^{1} \\
\text { (vs. "female") }\end{array}$ & $\begin{array}{l}0.043 \\
(0.229)\end{array}$ & Age & $\begin{array}{l}0.008 \\
(0.015)\end{array}$ \\
\hline $\begin{array}{l}\text { Black respondent }{ }^{2} \\
\text { (vs. "white") }\end{array}$ & $\begin{array}{l}-0.387 \\
(0.719)\end{array}$ & Income & $\begin{array}{l}-0.041^{*} \\
(0.022)\end{array}$ \\
\hline $\begin{array}{l}\text { Employed for wages } \\
\text { (vs. "unemployed") }\end{array}$ & $\begin{array}{l}0.275 \\
(0.533)\end{array}$ & Education attainment & $\begin{array}{l}-0.176^{*} \\
(0.092)\end{array}$ \\
\hline \multicolumn{2}{|c|}{ OD registration (vs. "No and never considered") } & \multicolumn{2}{|l|}{ Religion $^{4}$ (vs. agnostic) } \\
\hline No but have considered & $\begin{array}{l}1.251^{* * *} \\
(0.471)\end{array}$ & Muslim & $\begin{array}{l}-0.102 \\
(1.532)\end{array}$ \\
\hline Yes & $\begin{array}{l}2.378^{\star * \star} \\
(0.404)\end{array}$ & $\begin{array}{l}\text { Other Christian } \\
\text { affiliations }\end{array}$ & $\begin{array}{l}-1.130^{* *} \\
(0.503)\end{array}$ \\
\hline Vignettes & 252 & & \\
\hline Observations & 756 & & \\
\hline $\mathrm{R}^{2}$ & 0.403 & & \\
\hline
\end{tabular}

Note: robust standard errors in parentheses; ${ }^{* * *} p<0.01, * * p<0.05,{ }^{*} p<0.1$

Categories (with no significant relationships, or with very small observations) not shown above included: ${ }^{1}$ other gender. ${ }^{2}$ Asian, Hispanic or Latino, mixed-race, Native American, Pacific Islander. ${ }^{3}$ homemaker, student, selfemployed, unable to work. ${ }^{4}$ Atheist, Buddhist, Catholic, Hindu, Jewish, Jehovah's Witness, Mormon, not religious, Orthodox Christian, other religion, Protestant 